\title{
ENVIRONMENTAL PERFORMANCE INDICATORS FOR ASSESSING SUSTAINABILITY OF PROJECTS IN THE GHANAIAN CONSTRUCTION INDUSTRY
}

\begin{abstract}
Purpose- Recent reports based on the Sustainable Development Goals (SDGs) have revealed that no country is in line with achieving the targets of the 2030 Agenda for Sustainable Development, with the slowest progress being witnessed mainly on goals focused on the environment. This study examines environmental performance indicators for assessing the sustainability of building projects in the Ghanaian construction industry.

Design/methodology/approach- The study uses an explanatory sequential design with an initial quantitative instrument phase, followed by a qualitative data collection phase. An extensive critical comparative review of the literature resulted in the identification of ten environmental sustainability indicators. One hundred and sixty-seven questionnaire responses based upon these indicators from the Ghanaian construction industry were received. Data was coded with SPSS v22, analysed descriptively, and via inferential analysis. This data was then validated through semi-structured interviews with six interviewees who are Fellows of their respective professional bodies, a Senior Academic (Professor in construction project delivery), and a government official. Data obtained from the semi-structured validation interviews were analysed through the side-by-side comparison of the qualitative data with the quantitative data.

Findings- The findings from the study suggest that all the indicators were important in assessing building projects' environmental sustainability across the entire life cycle. Key among the identified indicators are the effects of the project on 'water quality, air quality, energy use and conservation, and environmental compliance and management'. The interviewees further agreed to and confirmed the importance of these identified indicators for assessing the environmental sustainability of building projects in Ghana.

Originality/value- Compared to existing studies, this study adopts the exploratory sequential design to identify and examine the critical indicators in assessing the environmental sustainability across the entire lifecycle of building projects in a typical developing country setting, i.e. Ghana. It reveals areas of prime concern in the drive to place the local construction industry on a trajectory towards achieving environmental sustainability.
\end{abstract}

Keywords: Sustainable development goals; Environmental sustainability; sustainability indicators; Sustainability assessment; Sustainability performance; Building projects; Ghana 


\section{Introduction}

The adoption of the Sustainable Development Goals (SDGs) in 2015 by the United Nations marked a turning point for the overall global development agenda (Opoku, 2016). According to the United Nations Environment Programme (UNEP) (2013), the SDGs present a clearer picture of the interaction between social, economic, and environmental dimensions of sustainability, a failing of the phased-out Millennium Development Goals (MDGs). Achieving the SDGs by 2030 is a very ambitious target dependent on the concerted effort of stakeholders worldwide. Quite recently, a report by the Sustainable Development Solutions Network (SDSN) revealed that as yet, no country had made significant progress towards achieving the SDGs by the 2030 target, with the slowest progress recorded among the environment-focused goals (Arora and Mishra, 2019; Sachs et al., 2019). It is widely accepted that the construction industry plays a pivotal role in the achievement of sustainable development (Opoku and Fortune, 2013) as its activities have been reported to have a more significant impact on the environment, society, and economy than other industries (Shen et al., 2007).

The construction sector is a significant contributor to sustainable development, with its environmental protection, economic growth, and social progress highly undeniable (Tupenaite et al., 2017). However, this industry has been linked to inefficient resource utilisation, high volumes of waste generation (Rahimian et al., 2017), and low productivity (Sfakianaki, 2015). In response to this permeating challenge, there is a global demand for the widespread adoption of sustainable practices in the construction sector (Opoku and Fortune, 2013). The construction industry has attracted acute criticism due to its detrimental effects on the natural environment (Asman et al., 2019). Sustainable construction, perceived as a subset of sustainable development, is also conceived as the industry's contribution to sustainable development (Kibert, 2013). The environmental dimension of sustainable construction relates to issues bordering on optimisation of energy, water, materials, land usage, resource reuse and recycling, renewable resources usage, minimisation of air, land, and water pollution, amongst a host of others (Shen et al., 2007).

In most developing countries, the construction industry's environmental concerns have been sidelined as the focus of the development agenda lies in providing socio-economic reliefs. This situation has led to an imbalance of the sustainability tripod (Du Plessis, 2002). Similarly, Wu et al. (2020) opined that, in the pursuit of development, developing economies place a higher premium on economic efficiency at the expense of ecological conservation and social responsibility, a departure from the balanced approach projected in sustainable development. Correspondingly, Wang (2014) added that the effect of construction-related activities on the environment is more pronounced in developing countries than in the developed world. Additionally, Arora and Mishra (2019) indicated that progress made towards achieving the environment-related targets (SDGs 6, 7, 12, 13,14 , and 15) lags among the SDGs. On the back of these issues, the practicality of championing sound construction practices for a healthier and cleaner environment cannot be underestimated.

The attainment of sustainable development would be elusive until due attention is given to sustainability performance assessment across the entire lifecycle of projects (Tupenaite et al., 2017; Shen et al., 2007). Correspondingly, the realisation of sustainability goals is linked to the possibility of assessing the sustainability of development efforts (Patil et al., 2016). Globally, there is a proliferation of methodologies, tools, 
and frameworks that offer a means of assessing sustainability performance across the lifecycle of construction and infrastructure projects (Siew et al., 2016). Some of the mainstream rating tools developed by recognised construction industry agencies include the Building Research Establishment Environmental Assessment Methodology (BREEAM), Leadership in Energy and Environmental Design (LEED), Comprehensive Assessment System for Building Energy Efficiency (CASBEE), and Green Star (Alyami et al., 2013). In the views of Rodriguez-Trejo et al. (2017), the increased importance of the social, economic, and environmental values within the main building sustainability rating tools makes the search for key performance indicators and the selection of adequate scales a cornerstone to define a decision support system for early design stages. Also, as Kivilä et al. (2017) mentioned, in a projectized setting, the sustainability of the delivery process is equally important as the sustainability of the final product as both process and product have considerable environmental, social, and economic impacts. Hence, it is not enough to strive for a sustainable product while the process involved fails to meet sustainability requirements (Kivilä et al., 2017). Enshassi et al. (2016) therefore indicated that in trying to identify any sustainability (i.e., either environmental, social, or economic) indicators, especially for the construction industry, such indicators must not only focus on a specific phase of the project but all the potential phases.

Over the years, several researchers have offered different approaches to improve the sustainability of the construction industry (Yu et al., 2018). These approaches include the green innovation of construction methods (Yu et al., 2017), promoting green building technologies (Lin, 2016), reusing waste materials to reduce environmental impacts (Markiv et al., 2016), among other things. Again, some other researchers have established different industrial or national indicator systems to evaluate the sustainability of the construction sector of specific countries (Chen, 2007; Chang, 2000). Some of these evaluation systems have been criticised as being comprehensive in assessing the sustainability of the construction industry, but less helpful in developing strategies to improve construction projects' sustainability (Yu et al., 2018). To counter these evaluation systems' weaknesses, some more specific approaches that focus on the sustainability of construction projects were proposed by Labuschagne and Brent (2004, 2005).

As proposed by Labuschagne and Brent (2004, 2005), the evaluation system evaluates the environmental impacts of new products during the innovation project lifecycle in the manufacturing sector. Notwithstanding, since such evaluation systems are country and sector-specific in nature, researchers in different countries and sectors are encouraged to develop such indicator sets that best suit countries and sectors of origin (Yu et al., 2018). This current study seeks to contribute to the existing state-of-the-art by examining key indicator sets for assessing the environmental sustainability of building construction projects in Ghana. The decision to focus this study on examining the environmental indicators is based on the assertion of Wang (2014), who indicated that the effect of construction-related activities on the environment is believed to be more pronounced in developing countries (in the current state Ghana) in comparison to the developed world. Arora and Mishra (2019) had also indicated that among the SDGs, progress made towards the achievement of the environment-related targets (SDGs 6, 7, 12, 13, 14, and 15) lags far behind the other goals. This current study seeks to make contributions in the light of these two strong statements as well. 
2. Though most of the similar works conducted in this area adopted the three-pillar perspective (i.e., environmental, social and economic sustainability of construction projects), several essential issues must be considered in developing an appropriate sustainability indicator system for a construction project (Yu et al., 2018). These issues are listed to include the following: a more comprehensive angle of sustainability (Marcelino-Sádaba et al., 2015); restricting the number of indicators to ensure a more practical and cost-effective implementation (Fernández-Sánchez and Rodríguez-López, 2010); not restricting the indicator set to only the construction project lifecycle, but also the facility lifecycle (Hill and Bowen, 1997); and, ensuring that the indicator sets are relevant to project operations and tasks for management effectiveness (Marcelino-Sádaba et al., 2015). As a significant contribution to this state-of-the-art, the current study is designed to consider all these critical issues raised by researchers in the field. This study therefore aims to examine the environmental performance indicators for assessing the sustainability of building projects in the Ghanaian construction industry. To achieve this aim, two objectives were set: 1) To identify key environmental performance indicators for assessing the sustainability of building projects in the Ghanaian construction industry; 2) To discuss the key environmental performance indicators for assessing the sustainability of building projects in the Ghanaian construction industry as identified from the study. Literature review

\subsection{The construction industry and the sustainable development goals}

Like the other sectors of every economy, sustainable development goals also concern the construction industry. Realigning a country's construction sector helps significantly improve and achieve global sustainable development goals (Wieser et al., 2019). According to Arora and Mishra (2019, p. 339), the environmentally aligned goals focus on "clean water and sanitation, affordable and clean energy, sustainable consumption of natural resources, climate change, life below water and on terrestrial ecosystems, halting biodiversity loss and combating land degradation and desertification". The construction industry is resource-intensive, consuming about $40 \%$ to $75 \%$ of natural resources (Vanderley, 2011). It relies principally on the natural environment for inputs required for its operation and sustenance (Du Plessis, 2002). A report by the International Resource Panel (IRP) in 2017 also revealed that buildings consume about $25 \%$ of global water, both in construction and displacement (IRP, 2017; Wieser et al., 2019). About 36\% of the final energy use in 2017 was attributed to the construction sector (Global Alliance for Buildings and Construction, 2019). Furthermore, the industry was responsible for about 39\% of greenhouse gas emissions in 2017 (Wieser et al., 2019). The industry's contribution to these goals' disturbances is well reported in the literature (Arora and Mishra, 2019; Wieser $e t$ al., 2019).

The construction industry is central to delivering many government policies for sustainable development through the provision of buildings and other critical infrastructure projects (Opoku, 2016). By the year 2030, it is projected that about 60\% of the world's population (especially in developing countries) will be living in urban areas (Opoku, 2016). Therefore, the construction industry is needed to provide sustainable infrastructure and facilities that are resilient to possible environmental risks, sustainable in its construction and use, and that will allow the successful operation of businesses and services to enhance the efforts towards achieving the SDGs (Opoku, 2016). 


\subsection{The Ghanaian Construction Industry (GCI)}

Like that of many other countries, the GCI is a significant contributor to the Ghanaian economy, although it faces many challenges (Agyekum et al., 2018; Osei, 2013). The GCI has failed to keep pace with modern trends and is in grave need of invigoration to stay abreast with current global industry trends (Ofori-Kuragu et al., 2017). The adoption of sustainable construction has been slow (Ampratwum et al., 2019; Opoku et al., 2019). The industry's carbon footprint is at upsetting levels compared to global standards (Ofori-Kuragu et al., 2017). Ghana's green building market is in its infancy and is marked by a slow pace of adoption (Darko et al., 2018; Addy et al., 2020). Even though there is an increasing supply of buildings, sustainability is not a significant consideration when making project decisions (Addy et al., 2020). Addy et al. (2017) stated that the GCI is beset with many challenges that impinge on the widespread adoption of sustainable practices at the planning, design, and construction stages of projects. The challenges constraining efforts to place the industry on a sustainable trajectory have been reported by many (see Agyekum et al., 2021; Agyekum et al., 2020; Djokoto et al., 2014; Ametepey et al., 2015; Chan et al., 2018; Agyekum et al., 2019; Opoku et al., 2019; Addy et al., 2020).

\subsection{Sustainability indicators across the lifecycle of projects}

The Royal Institute of British Architects (RIBA) explained a construction project's lifecycle process to encompass conception and feasibility studies, engineering and design, procurement, construction, start-up and implementation, and operation or utilisation (Enshassi et al., 2016). Therefore, the lifecycle assessment of a project is a comprehensive approach to examining the complexities of interaction between the built and natural environment through the impact of the environment on an entire building (Younan, 2011). Each of these processes as explained by the RIBA has a role to play in achieving sustainability of the built environment.

Sustainability is a dense and multifarious concept (Zhou et al., 2013), and a general approach to measuring sustainability performance in the construction sector is the use of indicator sets (Fernández-Sánchez and Rodríguez-López, 2010). Indicators condense large and complex information into a recognisable format and offer a snapshot of a system's state, providing a basis for making further decisions (Bossel, 2001). Hassan (2016) described a sustainability indicator as a measurable variable (quantitative or qualitative) that defines a preferable outcome geared towards attaining sustainability goals. Fiksel et al. (2012) also described it as an assessable aspect of environmental, economic, or social systems that enables variations in system characteristics to be monitored.

Various researchers have developed indicator sets for assessing construction sustainability, specific to project types and countries. For instance, Ugwu et al. (2006) developed sustainability key performance indicators and mapped them to various construction projects. Also, Yao (2007) indicated that existing assessments are focused on assessing merely environmental performance, with the other dimensions of sustainability 
suffering neglect. To fill this gap, Yao (2007) developed a list of 22 indicators for holistically assessing large-scale infrastructure projects' sustainability performance at the feasibility stage, based on which the sustainability index of varying alternatives could be computed by the utilisation of a multicriteria-based scoring model. Fernández-Sánchez and Rodríguez-López (2010) also developed a set of 30 indicators applicable to linear infrastructure projects in Spain by initially advancing a methodology for the identification and selection of sustainability indicators in construction project management.

Similarly, Shen et al. (2011) formulated a list of key assessment indicators for guiding the assessment of infrastructure sustainability before implementation. Also, Reddy (2016) developed a list of 22 key assessment indicators after reporting that existing approaches to assessing infrastructure projects' sustainability focused singularly on environmental or economic issues, hence, could not deal with sustainability holistically. In this regard, Reddy's indicator set included technical indicators while maintaining various economic and environmental indicators. Yu et al. (2018) recently developed a sustainability assessment system applicable to all stages of a building project, predicated on the three-pillar conception of sustainability for the Taiwanese construction industry.

From this comparative review, it is clear that the indicators developed are country-specific and geared towards all the aspects of sustainability. Particular indicators and their significances are highly dependent on the environmental, social, and economic contexts of their use. This problem motivates most researchers to develop their national sustainability assessment systems (Tupenaite et al., 2017). Unfortunately, from an environmental perspective, the construction sector is reported to do more harm than good (Tupenaite et al., 2017).

\subsection{Environmental Sustainability Indicators (ENSIs) across project lifecycles}

The holistic understanding of sustainability necessitates environmental and ecological indicators related to the use of natural resources and those associated with society and the economy (Tupenaite et al., 2017). The environmental dimension of sustainable construction cuts across the entire project lifecycle and addresses issues relating to waste management, energy use, water quality and consumption, biodiversity, air quality, land (soil) contamination, light pollution, noise emissions, and environmental management ( Yu et al., 2018; Enshassi et al., 2016; FernándezSánchez and Rodríguez-López, 2010; Pitt et al., 2009; Shen et al., 2007). Discussed below are key environmental sustainability performance indicators necessary for the various phases of building construction projects.

\subsubsection{Energy use and conservation}

Construction activities consume large amounts of energy, a considerable portion of which is associated with construction machinery's operation (Addy et al., 2017). Energy efficiency has risen to the fore as a critical component in the drive to attain a sustainable environment (Adinyira et al., 2018; Addy et al., 2017). The common forms of energy used during construction include diesel, electricity, petrol, and gas. Owusu and Asumadu-Sarkodie (2016) indicated that the rationale behind energy conservation is to decrease the dependence on fossil fuels and scale up alternative energy sources, including solar, wind, water, and geothermal energy. 


\subsubsection{Water quality}

Both surface water and groundwater are susceptible to pollution from construction site activities (Murnane et al., 2006). Construction activities that can seriously impact surface water quality include disposal of groundwater to surface water, refueling activities, uncontrolled waste and chemical handling, rampant soil erosion caused by unprotected stripped land surfaces, and polluted discharges from site, among others (Murnane et al., 2006). Sediments, the primary surface water pollutants on construction sites, which arise from erosion of stripped soil surfaces by runoff can be forestalled by adopting suitable erosion and sediment controls (Houser and Pruess, 2009). Pollution of surface water bodies results in reduced quality, changes in volume and destruction of aquatic habitats, loss of amenity and recreational value, and importantly loss of potable water supply (Masters-Williams et al., 2001). Groundwater contamination is a critical issue since the effects are long-lasting and usually involve highly challenging and expensive procedures to remediate (Murnane et al., 2006). Activities that may contaminate groundwater on construction projects include piling, drilling boreholes, excavations, fuel spillage, uncontrolled waste disposal, and washing operations, while common pollutants include chemicals, metals, hydrocarbons, and salts (Murnane et al., 2006).

\subsubsection{Water use and conservation}

As a resource-intensive industry, construction consumes significant natural resources, and water is not excluded (Waidyasekara et al., 2016). Water is required on building sites for varying purposes including, drinking, welfare uses, sanitary uses, and construction-related activities like concrete batching, washing, cleaning, and dust suppression (Murnane et al., 2006). Sources of water supply vary from direct connection to mains, tanker services, borehole/well, or surface water sources depending on the site's geographical location. Given the general perception that water is an unlimited resource, misuse is not uncommon on construction sites (Waidyasekara et al., 2012). A strategy to improve water efficiency during construction should include measures to reduce water wastage, enhance water-consuming operations efficiency, and promote exploration of alternative sustainable sources of water (Waylen et al., 2011).

\subsubsection{Air quality}

Air pollution is becoming a global environmental challenge, as industrial development progresses faster (Tong et al., 2018). Construction activities may be responsible for air quality impairment through activities that generate dust and exhaust emissions from construction machinery and transport vehicles (Ioana-Alina and Nicoleta, 2017). Construction-related dust is responsible for significant pollution of the environment and has severe impacts on human beings' physical health (Tong et al., 2018). Emissions from construction sites may irritate the eyes and skin. They may compromise the respiratory system, ultimately leading to damaging acute or chronic effects on human health, depending on the length of exposure (Sadler, 2005).

\subsubsection{Environmental compliance and management}


Environmental management comprises activities that control and minimise the impact of human operations on the environment to ensure the preservation of the environment (Yalley et al., 2013). The technical manual of the Green Star office rating tool developed by the Green Building Council South Africa (GBCSA) stipulates that a contractor needs to maintain a detailed Environmental Management Plan (EMP) as well as an Environmental Management System (EMS), preferably, one that is ISO 13001 certified (for projects of considerable size), during the project execution phase (GBCSA, 2014). As indicated by Murnane et al. (2006), the EMP translates the EMS into an action plan for project-level execution and details the responsibilities and procedures for environmental management. The significant impact of construction activities requires that responsibility be taken in the form of effective management procedures to tone down or eliminate its environmental impacts (GBCSA, 2014).

\subsubsection{Construction waste management (CWM)}

CWM is a critical component of sustainable construction, as the construction industry is a significant consumer of resources and an important contributor to waste generation (Dania et al., 2007). CWM transcends mere waste disposal; instead, it comprises strategies to utilise construction resources effectively, with the overall view of reducing wastage and repurposing generated waste (Dania et al., 2007). Unfortunately, a bulk of construction and demolition waste ends up on the disposal pile, although a high proportion of such waste can be recycled or reused (GBCSA, 2014). Waste management has become a topical issue due to the unavailability of disposal sites and the associated environmental ramifications of uncontrolled waste generation and disposal (GBCSA, 2014). The GBCSA (2014) recommends that a construction site has a comprehensive waste management plan (WMP) that details all waste handling protocols. Throughout the entire construction phase, the WMP should comply with waste monitoring, recycling, reuse, and spell out personnel responsibilities for specific tasks.

\subsubsection{Land/soil pollution}

Soil is prone to pollution from physical and chemical environmental stressors; thus, land can deteriorate physically to compromise its usefulness or be contaminated by chemical pollutants (Vallero and Vallero, 2019). A soil pollutant is any agent that compromises the quality, texture, and mineral composition of the soil or that causes a disruption in the biological balance of organisms present in the soil (Ashraf et al., 2014). Common soil pollutants resulting from construction activities include petroleum hydrocarbons, heavy metals, pesticides, solvents, and run-off. Their effects include groundwater contamination, increased erosion, ecological imbalance, and reduced soil fertility and productivity (Ashraf $e t$ al., 2014).

\subsubsection{Light pollution}

Light pollution occurs when light travels up into the night sky or spills onto neighbouring properties (GBCSA, 2014) and is associated with the excessive use of illumination devices at night (Zielińska-Dabkowska et al., 2020). The impact of light pollution that results from construction activities may include the disruption of human beings and animals (Elsahragty and Kim, 2015). Light pollution also impacts nocturnal creatures, 
emission of additional greenhouse gases to power the lights, a hindrance to professional and recreational astronomy, and inhibition of the navigation of migratory birds (Elsahragty and Kim, 2015).

\subsubsection{Noise pollution}

Noise is generally defined as an unwanted sound that potentially disrupts one's quality of life (Bhosale, 2017). Noise has become a constituent part of the urban scene, and the construction industry contributes its bit through site operations which are inherently noise-generating activities (Ballesteros et al., 2010). Noise pollution from on-site construction activities is a significant disruption to the environment, affecting construction workers and the residents of the local community (Geetha and Ambika, 2015).

\subsubsection{Impact on biodiversity and ecology}

The built and natural environments have an interdependent relationship, and their interactions affect the planet significantly (Opoku, 2019). Biodiversity is a scientific term that describes the different varieties of all living organisms from all sources (terrestrial, marina, and aquatic) and their ecosystems, encompassing diversity within species, between species, and of ecosystems (Roe et al., 2019). As a heavy consumer of resources, the construction industry is seen as a significant contributor to biodiversity loss (Opoku, 2019). Although the construction industry and development initiatives, in general, are crucial to the preservation of biodiversity, historically, biodiversity conservation has not been of prime concern in development efforts (Opoku, 2019). Biodiversity loss has far-reaching effects, going beyond its immediate impact on plants and animals to inhibit the ecosystem's ability to protect the built environment from natural disasters like floods and wildfires (Opoku, 2019).

Table I summarizes the various environmentally sustainable performance indicators and the references from which they were sourced.

\section{INSERT TABLE I}

Fernández-Sánchez and Rodríguez-López (2010) proposed a general methodology to examine the sustainability indicators of construction projects. The processes involved include the following: reviewing documentation, compiling information through surveys with key stakeholders, compiling information through interviews with domain experts, brainstorming by the project participants, comparison with other areas and existing tools, analysing by checklists related to similar previous projects, and using diagramming techniques to establish relationships between system elements and their causality (Yu et al., 2018). However, Marcelino-Sádaba et al. (2015) believe that the two most adopted approaches to examining such indicator sets are documentation and literature reviews and expert surveys. These two approaches may work well in adopting a mixed research methodology. In this current study, the two approaches are used and further expounded in the methodology in Section 3. 


\section{Methodology}

The study adopted a mixed-method approach. According to Wisdom and Creswell (2013), there are five primary mixed-methods design approaches. These approaches include validating findings using quantitative and qualitative data sources, using qualitative data to explore quantitative results, developing survey instruments, using qualitative data to augment a quantitative outcome of a study, and involving community-based stakeholders (Wisdom and Creswell, 2013). Following the widely used methodology in studies like this (Yu et al., 2018; Marcelino-Sádaba et al., 2015), this study adopted a design that uses qualitative data to explore the quantitative findings. This design is exploratory sequential and involves two phases, i.e. 1) an initial quantitative instrument phase followed by 2) a qualitative data collection phase. Adopting this approach, the paper through a comparative review of related literature, identified the indicator sets. The indicator sets were then used in a questionnaire survey among key stakeholders. The findings from the questionnaire survey were then validated through interviews with key stakeholders. As an issue of novelty, this design further helped establish how respondents' personal experiences regarding the key environmental sustainability indicators matched the questionnaire survey results.

\subsection{Identification of indicators}

It is crucial to formulate a comprehensive list of items affecting sustainability by leveraging information available in existing guidelines, frameworks, and rating systems in identifying indicators. Following an extensive review of related literature, ten indicators (shown in Table I) were identified. An essential step towards addressing sustainability challenges in developing countries is to examine indicators through the collaborative and effective participation of all relevant stakeholders (Ugwu and Haupt, 2007). In this vein, the indicator examination process culminated with a questionnaire-based assessment of the views of relevant stakeholders in the local construction industry. Data obtained through the questionnaire survey was validated through qualitative means.

\subsection{Design of the instrument and survey administration}

A questionnaire was developed and divided into two sections, i.e., the respondents' demographic information and respondents' assessment of the ten performance indicators' significance. This data collection method was considered appropriate because of the study's nature, which sought to assess the identified indicators to establish their relative significance quantitatively. After designing the instrument, it was validated through expert interviews with six experienced professionals in the GCI - a Chief Quantity Surveyor, a Senior Architect, one Principal Engineer, a Construction Project Manager, a Professor of construction project delivery, and a government official. The feedback from these professionals was positive, i.e., they all agreed to the inclusion of the various variables in the questionnaire. The respondents were required to rate the significance of the various ENSIs on a five-point Likert scale, where $1=$ not significant; 2 = fairly significant; $3=$ significant; $4=$ very significant; 5 = extremely significant. 
The questionnaire was distributed face-to-face to key industry practitioners (building contractors, consultants, clients, and developers) and academics in Ghana with knowledge and experience in delivering sustainable building projects. Academics were selected based on their research and teaching activity in sustainable construction, while practitioners were selected based on their membership with recognised professional bodies in the country. Though there exist quite a good number of built environment professionals within Ghana, getting those professionals with in-depth knowledge concerning the issue under investigation was challenging. Readily available participants were located using purposive sampling, and by referrals using the snowball method, other professionals were contacted for the study. The purposive and snowball sampling approaches became relevant because the researchers did not have a clear view of the population to which they were seeking to generalize, hence, making it difficult to compile a complete sampling frame for the study. A total of 330 questionnaires were administered, out of which 167 responses, representing approximately $51 \%$, were received and used for the statistical analysis.

\subsection{Quantitative data analysis and results}

Data from the survey were analysed using the IBM SPSS Statistics software version 22. Both descriptive and inferential statistical analysis was carried out on the quantitative data.

\subsubsection{Profile of Respondents}

For every research conducted, there is the need to ensure that the population under study are fairly represented. As a matter of fact, attention is now placed on increasing the diversity of research participants and presenting the demographic characteristics of such participants when presenting findings in journal articles (Hammer, 2011). Information such as the age, gender, level of education, profession, etc. of participants are all important to enable the researchers avoid assuming the stance of "absolutism" (i.e., assuming that the phenomenon of interest is the same regardless of the backgrounds of the respondents) (Beins, 2009). This study was conducted in the Ghanaian construction industry which is made up of different people with diverse professions, ages, educational backgrounds, etc. As a result, not seeking the background information of such participants may cause the researchers to assume the "absolutism" stance which may not provide a true reflection of the phenomenon under investigation across the various participants. By obtaining the needed demographic characteristics of the respondents (i.e., education, type of organisation, etc.), the study assumed the "universalism" stance. This stance recognises that there may be universal psychological processes that manifest differently depending on the demographic characteristics of the respondents (Beins, 2009). However, this study was only interested in determining these demographic backgrounds of the respondents and not their influences on the outcome of the study. This was the case because it was important to first obtain the perceptions of the respondents concerning this general issue of sustainability, and when the specific mysteries surrounding the concept has been unravelled, future studies could then establish such relationships.

Out of the total number of 167 respondents, 58 (34.7\%) possessed bachelors' degrees, 4 (2.4\%) had postgraduate diplomas, 89 (53.3\%) had earned master's degrees, and $16(9.6 \%)$ possessed doctorate degrees. With regards to the distribution of respondents, $37(22.2 \%)$ were from 
client organisations, $27(16.2 \%)$ were from contractor organisations, $70(41.9 \%)$ were in consultancy firms, $9(5.4 \%)$ were engaged in government authorities, while $24(14.4 \%)$ worked with academic and research institutions.

\subsubsection{Reliability Analysis}

The scale's reliability was tested using Cronbach's alpha coefficient (CAC) (Pallant, 2016; George and Mallery, 2018). The CAC value recorded was 0.942 , indicating very high reliability of the scale (George and Mallery, 2018). None of the items recorded item-total correlations values below the threshold value of 0.30 , indicating a good correlation between the variables and the overall scale (Field, 2018) (see Table III).

\subsubsection{Mean Score Ranking (MSR)}

MSR was used to determine the relative significance of each ENSI, using the formula:

Mean Score $=\frac{\Sigma(\mathrm{f} \mathrm{x} \mathrm{r})}{\mathrm{N}}$; where

$\mathrm{r}=$ respondent's perceived significance of indicator (ranging from 1 to 5 ), $\mathrm{f}=$ frequency of each score, and $\mathrm{N}=$ total number of respondents.

The ranking was done based on the mean values arranged in descending order. Where there were ties, the standard deviation (SD) values served as a tiebreaker, with the indicator that recorded a lower SD ranking higher. A test value of 3.5 (which approximates the scale point of 4), meaning "very significant", was used regarding the MSR. Thus, if an indicator obtains a mean score that is significantly greater than 3.5, then it implies that the indicator is significant. From Table II, the overall mean values of the ENSIs range from 3.67 to 4.50 , indicating the relative significance of all the indicators. However, individual results for the specific stakeholder groups showed different mean values across the various indicators. To determine the statistical significance of these differences, the Kruskal-Wallis test was carried out to ascertain the existence of significant differences between the stakeholder groups' views regarding the significance of the various ENSIs (Aldrich and Cunningham, 2016).

\subsubsection{Normality Testing}

It is essential to check for normality before any relevant statistical analysis to assuage doubts about validity and reliability and avoid erroneous inferences from findings (Das and Imon, 2016). This was done by examining kurtosis, skewness, and results of the Shapiro-Wilk (SW) test. From Table III, all the $\mathrm{Z}$-score values of skewness fell outside the acceptable range $(-1.96 \leq \mathrm{Z} \leq 1.96)$. Also, except for ENV01, ENV02, ENV05, and ENV10, all the z-score values of kurtosis fell outside the permissible range, rendering the data non-normal (Corder and Foreman, 2014; Field, 2018). For the SW test, the $p$-values recorded were below the significance level of 0.05 in each case, indicating that the various variables' distribution is statistically significantly different from a normal distribution, confirming the preliminary conclusion.

\subsubsection{Kruskal-Wallis (KW) Test}


The KW test was carried out to ascertain whether the significance accorded to the respective ENSIs varied across the stakeholder groups (clients, consultants, contractors, government authorities, and academics/researchers). The KW test was employed in related studies of Patil et al. (2016) and Zhou et al. (2013). The null hypothesis for the KW test was that: "there is no significant difference regarding the significance of the ENSIs across the stakeholder groups." The test revealed statistically significant differences in the level of significance accorded the ENSIs across the five stakeholder groups. These differences are evident in the $p$-values, which fell below the significance level of 0.05 , necessitating the rejection of the null hypothesis favouring the alternative hypothesis in each case (Table III).

\subsubsection{Post Hoc Analysis}

To identify the specific group pairs that exhibited significant differences, post hoc analysis (pairwise comparison) was performed (Corder and Foreman, 2014). Pairwise comparisons entail performing the Mann-Whitney test (a non-parametric procedure for comparing two unrelated samples) for all the possible group pairs, but with an adjusted $p$-value (Bonferroni adjustment) to ensure that the rate of error across all the tests performed does not exceed 5\% (Pallant, 2016; Field, 2018; Corder and Foreman, 2014). The results from the pairwise comparison is shown in Table IV.

\subsection{Design of interview guide, conducting interviews and analysing qualitative data}

This phase of the study was initiated following the results from the quantitative phase. The idea was to get the respondents to indicate how each of the key indicators significantly contributed to building construction projects' environmental sustainability. An interview guide was prepared to seek the views of the interviewees. The interview questions only centred around the four key indicators that were identified through the quantitative analysis.

Six key respondents with backgrounds like those used in the piloting were interviewed. These respondents were people with enough experience on issues concerning sustainability in the building construction industry. All the six interviewees were Fellows of their respective professional bodies (namely, GhIS, GIA, GhIE, CIOB), a Senior Academic (Professor in construction project delivery), and a government official. Many articles, book chapters, and books recommend guidance and offer anywhere from 5 to 50 participants as adequate in a qualitative study (Yin, 2014). Parse (1990) also suggested that for a qualitative study where researchers seek to obtain rich data, two to ten participants are recommended.

Notwithstanding, depending on the context of the research being conducted, researchers can settle on any required number provided they are in the position to examine and assess all the views of the interviewees critically. Other sustainability-related studies have used between two to ten participants (Agyekum et al., 2020; Agyekum et al., 2019; Ampratwum et al., 2019; Opoku et al., 2019; Opoku et al., 2019). Therefore, the six respondents for this study's qualitative bit were adequate to provide the information needed for this study. 
The qualitative research approach enables the researcher to obtain in-depth views and experiences of the respondents about the phenomena under study rather than the researcher's assumptions (Polit and Beck, 2017). Mason (2002) also iterated that it enables the researcher to focus on how the phenomenon under investigation is construed, understood, and experienced. Therefore, the interviews became necessary in this study because the research sought to obtain the interviewees' verbatim comments regarding how the key indicators identified contributed to the environmental sustainability of building construction projects. The interviews were also essential to further validate the findings of the quantitative data during the discussion. The interviewees were contacted by telephone because of their busy schedules.

Following the design adopted, data obtained from the semi-structured validation interviews were analysed through the side-by-side comparison of the qualitative data with the quantitative data.

\section{Discussing the quantitative results and validating them with the qualitative data}

The MSR (with mean value $=3.5$ ) results of the significant indicators are shown in Table II. From the ranking, all the 10 indicators examined are generally perceived to be significant for assessing the environmental sustainability of building projects at the various phases of projects. The ranking of the 10 indicators further revealed the topmost quarter include: Effect on water quality (ENV06) [MS $=4.50, S D=0.667]$; Effect on air quality (ENV03) $[M S=4.40, S D=0.760]$; Energy use and conservation (ENV09) $[M S=4.35$, SD = 0.769]; and Environmental Compliance and Management (ENV01) $[M S=4.34, S D=0.718]$. The two least, though significant indicators according to the respondents include: Noise pollution (ENV04) [MS =4.20, SD =0.696]; and Light pollution (ENV05) [MS = 3.67, SD =0.908]. This section discusses the results obtained from the quantitative analysis, followed by its validation with the qualitative data.

\subsection{Key Environmental Sustainability Indicators}

According to Kamali and Hewage (2015), a significant step to evaluating buildings' sustainability is investigating the existing sustainability performance indicators. There is no ideal cut-off point when determining critical indicators. However, the choice of an approach is dependent on the study's aim and the eventual use of its findings (Pakzad et al., 2017). The criteria for determining the key indicators followed a similar approach adopted in literature in identifying key indicators for assessing sustainable construction projects (Ugwu et al., 2006; Yao, 2007; Yao et al., 2011; Kamali and Hewage, 2015). In establishing the key ENSIs, the cut-off point was set at a mean value of 3.50; that is, an indicator with a mean value of 3.50 or above was considered significant. Per this criterion, all the candidate ENSIs were deemed significant. However, for the sake of this discussion and the lack of space, the emphasis was laid on the indicators ranked within the top quarter.

\subsubsection{Effect on water quality}

The effect on water quality (ENV06) emerged as the most significant indicator. Literature reports on this indicator as key in the environmental sustainability of buildings (Yu et al., 2018; USGBC, 2018; Enshassi et al., 2016; Owusu and Asumadu-Sarkodie, 2016; Reddy, 2016; Yao et al., 2011; Shen et al., 2007). According to Kaatz et al. (2005), the adverse environmental effects of construction activities on water quality is 
extensively reported. When economies grow, more infrastructure and facilities are needed to sustain economic development (Enshassi et al., 2016). This puts more pressure on natural resources like water, with its impact severely felt on the environment and all living organisms (Majdalani et al., 2006). The challenge now has been the industry's ability to reduce its activities on a typically natural resource like water bodies. Freshwater is the most precious renewable natural resource and an essential requirement for various life forms' sustenance (Yeleliere et al., 2018). As indicated by Masters-Williams et al. (2001), construction site operations can have significant negative impacts on the quality of ground and surface water. Recent challenges with water treatment in Ghana, occasioned by heavy pollution of the country's freshwater sources and exacerbating the already problem-laden potable water supply system, may be accountable for ranking this indicator above all others.

The various phases of construction projects tend to impact water bodies; the impacts are much felt during the construction, operation, and deconstruction of homes (Enshassi et al., 2016). Therefore, to have a sound and a more sustainable industry that has little impact on water bodies, Enshassi et al. (2016) recommend to all key stakeholders involved in contracts to take leadership roles in such transformations. In adding their voices, two of the interviewees had this to say:

The quality of the portable water is paramount and must be given serious thought at all phases of the project lifecycles, and most especially, during the construction and operation phases [Senior Academic, Senior Architect].

Like many sub-Saharan African nations, Ghana faces significant potable water supply challenges evinced in the erratic supply and limited access to water supply, even in the urban areas. As water access, affordability and quality remain pressing concerns (Afriyie and Ferber, 2018), the significance of this indicator, whose rationale is to reduce and ultimately eliminate threats to water quality, can be appreciated and even welcome. In a similar study by Shen et al. (2011) to identify sustainability indicators for China's infrastructure projects, this indicator was ranked as the most important in the environmental category. Enshassi et al. (2016) examined the factors that affected sustainability performance of construction projects during the project lifecycle phases in the Gaza Strip and revealed that examining the effect of the projects on the quality of water is an important environmental indicator that must be considered, especially during the inception, construction, and operation phases of the project. For instance, during the inception phase, it is advisable to examine the potential water pollution from the proposed project, including both surface and ground water (Enshassi et al., 2016). During the construction and operation phases, the impact of the project's consumption on water resources, and the release of poisonous substances as waste into water bodies must also be keenly checked. This finding further corroborates that reported in other countries like Taiwan (Yu et al., 2018), India (Reddy, 2016), and Korea (Yao et al., 2011). In all these studies, the impact of construction project activities on the quality of water are extensively reported.

\subsubsection{Effect on air quality}


The effect on air quality came out as the 2nd most significant indicator. Construction activities are responsible for generating air pollutants (greenhouse gas, exhaust emissions, fugitive dust, and off-gas emissions) that compromise the quality of air (Yan et al., 2019). The inevitable use of heavy equipment during construction is always an avenue for dust generation and exhaust emissions, significantly impacting local air quality, posing a health risk and contributing to climate change (Sadler, 2005). Air pollution has been identified as the most significant environmental killer (World Health Organisation, 2018). Its impact is reported on human health, on the environment and buildings.

On human health, it causes about 8 million deaths annually, and it is predominant in developing countries (World Health Organisation, 2018). From these deaths, 4.2 million results from exposure to ambient air pollution (with construction activities playing a pivotal role) (World Health Organisation, 2018). Airborne particles of dust resulting from construction activities, like hardwood or silica dust, contribute to severe health impacts, including silicosis, asthma, and heart diseases (Safety and Health, 2015). During the production phase of buildings, silica dust often produced during concrete manufacturing causes health risks across the built environment worldwide (World Green Building Council, WGBC, 2021). Environmentally, the emissions that impact the natural environment are from the operational phase of buildings and include those embodied in the building's lifecycle (i.e., both from the construction and demolition of the building). The global supply chain like excavation, brick and block making, transportation and demolition can be environmentally damaging (World Green Building Council, 2021; Ayarkwa et al., 2014).

On the building itself, the air pollution that is partially created directly impact their ability to perform in a sustainable way (WGBC, 2021). The Internal Energy Agency (2018) reported that during the building's operational phase, the increased use of air conditioning systems creates local micro-climate warming impacts due to the expulsion of hot air, which exacerbates the urban heat island effect. This notwithstanding, the global demand for air conditioners is expected to triple by 2050, indicating that the global air quality's negative impact is likely to increase (Internal Energy Agency, 2018). Similar studies conducted in Taiwan, China, Korea, and the likes report on this indicator's impact.

As identified in this study, this indicator seeks to ensure that local air quality is not compromised during the building's lifecycle. In cases where possible pollution may occur, pragmatic steps are taken to dampen its effects considerably. The effect would be to avert any potential health risks associated with inhaling polluted air and avoid causing a nuisance to residents. Although an ENSI, this indicator also has linkages with health and safety, a social sustainability indicator. This may account for its high overall ranking. In adding their voices, the interviewees indicated the following:

This indicator is important. Pollution reduction strategies must be considered during buildings' construction to preserve the air quality [Government Official, Project Manager]. 
Pollution that results from nitrates, carbonates, and the likes during the construction phase of building projects must be drastically reduced [Senior Academic].

This finding corroborates that reported in the literature (Yu et al., 2018; Enshassi et al., 2016; Yao et al., 2011; Fernández-Sánchez and Rodríguez-López, 2010; Shen et al., 2007; Yao, 2007). Enshassi et al. (2016) found that this indicator must be considered in all the project life cycle phases. They further stressed that during the inception phase this indicator must be given the utmost attention. The project stakeholders need to determine the potential air pollution that can emanate from the project and its impact on the local climate (Enshassi et al., 2016). Within the project construction phase, Shen et al. (2007) recommend that the generation of harmful substances like carbon dioxide, associated with some processes, must be conceived, and controlled. Yao et al. (2007) also agreed with Shen et al. (2007) and Enshassi et al. (2016) on this indicator. They reported that it is an important environmental sustainability indicator taken into consideration in the lifecycle of construction projects in Korea.

\subsubsection{Energy use and conservation}

Energy use and conservation was ranked as the 3rd most significant ENSI. Energy efficiency is an important component of green construction and is generally considered a critical success criterion (Addy et al., 2017; Vatalis et al., 2013). Though energy is used in the project lifecycle at different levels, the bulk energy is used during the operation phase ( $\mathrm{Hu}, 2017)$. Notwithstanding, it is important to account for and conserve energy usage at all levels of the project lifecycle (Talukhaba et al., 2013). Activities such as the mechanical plants used for transportation on construction sites, levelling, earthworks, lifting, mixing, compacting, etc., makes use of a significant portion of energy use (Talukhaba et al., 2013). Activities like demolition, transportation, excavation, and hoisting consume huge amounts of energy in the construction process.

Yüksek and Karadayi (2017) classified the building lifecycle into three phases (prebuilding, building, and post building phases). They indicated that each phase has a role to play when it comes to energy use and conservation. Within the prebuilding phase, energy-efficient design methods could be employed to make significant energy savings. Such methods can include site selection, site planning; building form; building plan and space organisation; design of building envelope; energy-efficient building material, energy-efficient landscape design, etc. (Yüksek and Karadayi, 2017). Within the building phase, building techniques that consume less energy is recommended-the energy used in construction changes based on the building systems. Hozatli and Günerhan (2015) confirmed this assertion and established that frame construction consumes less energy than reinforced concrete frame construction during its lifecycle. Within the post building phase where buildings are demolished, and materials are recycled, and or destroyed, energy must be conserved (Yüksek and Karadayi, 2017).

In Ghana, energy efficiency and conservation are esteemed as the go-to approaches in protecting energy resources (Gyamfi et al., 2018). Gyamfi et al. (2018) indicated that Ghana's electrical supply is erratic and fails to meet minimum reliability standards. In the short term, demand-side 
management strategies (reduction of energy use and demand) offer the most desirable solution to the situation since supply-side interventions require substantial capital investments and are conventionally time-consuming (Gyamfi et al., 2018). The views of some interviewees concerning this indicator are as follows:

In considering this environmental sustainability indicator during the lifecycle of building projects, priorities must be given to factors such as renewable energy and reduction in greenhouse gas emissions [Senior Architect, Project Manager].

\section{It would not be too bad to consider lighting efficiency as well [Government Official].}

Essentially, this indicator encourages the judicious use of energy during the construction phase and the exploration of renewable energy as a suitable alternative for construction operations, reducing the overdependence on non-renewable sources of energy. This finding also confirms that identified in related studies (Yu et al., 2018; Shen et al., 2011; Yao et al., 2011; Shan et al., 2007; Yao, 2007). According to Enshassi et al. (2016), though this indicator is vital in construction projects' lifecycle, it is also pronounced during the construction phase. This is evident in the various types of energies (e.g., electricity, oil, gas, coal, etc.) used for multiple construction phase activities. Shen et al. (2007) recommend that there must be serious effort to curtail the excessive use of various forms of energy at the construction and operation phases.

\subsubsection{Environmental compliance and management}

The 4th most significant ENSI is environmental compliance and management. Effective environmental management leads to evident gains in minimised resource utilization, reduction in energy use, improved construction processes, reduction in waste generation and its associated disposal costs, and increased use of renewable resources (GBCSA, 2014). However, Abramyan (2016) noted that though environmental management during the various phases of projects is a key priority of sustainable development, ensuring environmental compliance is challenging due to the lack of applicable standards. In a study focusing on construction-related environmental laws and policies in Ghana, Adjarko et al. (2016) concluded that environmental compliance within the Ghanaian construction industry is relatively low as many construction firms operate with little or no regard for environmental regulations. Adjarko et al. (2016) linked this unfortunate development to the Environmental Protection Agency (EPA) failure to ensure compliance due to its challenges such as inadequate logistics and insufficient staff strength. This indicator seeks to measure the extent to which environmental laws are adhered to during the construction phase. It is also essential to add that compliance audits lie within the EPA's purview and would be carried out using the project's pre-approved EMP as a benchmark (Yalley et al., 2013). Following this revelation from Adjarko et al. (2016), it can be iterated that for this indicator to perform well, the EPA in Ghana must ensure compliance. In adding their voices, the interviewees indicated that:

It is essential to consider specific innovative design processes and energy and atmospheric issues during both the design and construction phases of buildings [Senior Architect]. 
Materials and waste management, water efficiency and land use must be considered as critical [Project Manager, Engineer].

This finding corroborates that reported in the literature (USGBC, 2018; Enshassi et al., 2016; GBCSA, 2014; Yalley et al., 2013; Shen et al., 2007). Even though this indicator must be considered in all phases of the project lifecycle, its prevalence is felt during the construction, operation, and demolition phases of projects. Shen et al. (2007) postulated that there is a need for the key project resources to work at conserving the environment during the construction phase. There is also the need to ensure that established environmental management systems are adhered to. This can be achieved by applying environmental management standards like ISO 14000, project manuals, and the likes (Shen et al., 2007). Attention must also be paid to managing project environmental information through information management expertise and information management facilities. Shen et al. (2007) again recommend that construction companies adapt environmental management technologies (e.g. environmental experts, environmental management facilities, etc.) during this phase of the project life cycle. In their study in the Gaza Strip, Enshassi et al. (2016) also opined that there must be environmental consciousness training among employees during the operation phase of projects. They also encouraged the need to adopt environmentally friendly ways to operate facilities (Enshassi et al., 2016). During the project demolition phase, studies recommend adopting environment-friendly demolition methods like using technologies to alleviate the disturbance on eco-environment systems and neighbourhoods.

\section{INSERT TABLE II}

\section{INSERT TABLE III}

\section{INSERT TABLE IV}

\subsection{Summary of this studies contribution through a comparison with findings from other studies}

Compared to other sustainability indicators, environmental sustainability indicators are key and must be given the needed attention (Tupenaite et al., 2017). From the social aspect, buildings in whichever form offer accommodation and provide a sense of a secure future and strengthen communities. Economically, buildings are among the significant investments people make in their lifetimes (Tupenaite et al., 2017). Unfortunately, from the environmental point of view, the construction industry that produces these buildings have dire consequences on the environment.

The findings, as obtained in this study, can further be discussed in line with the literature. Al-Jebouri et al. (2017) developed a framework for a national sustainable building assessment system in Oman. Though their study addressed sustainability, it was emphasized that the system 
developed in their study must respect Oman's unique context in terms of its special geographical, political, cultural, and social features. From AlJebouri et al.'s (2017) study, the unique context of a particular country or region is essential when establishing sustainability indicators. In this context, it is in the right that the current study examined indicators peculiar to the Ghanaian construction industry setting. Unlike the study of AlJebouri et al. (2017), Kamali and Hewage (2015) examined the performance indicators for the sustainable assessment of buildings through an extensive literature review. In their study, different environmental performance criteria used in various publications were examined. Out of these criteria, 16 were identified to be vital in assessing the environmental performance of buildings. The key indicators were greenhouse gas emissions, indoor air quality, site disruption energy performance, water, and wastewater efficiency strategies (Kamali and Hewage, 2015). Though the indicators identified were similar to those identified in this current study, their study's result was based on secondary data across various countries. However, this present study identified primary data from professionals on key indicators peculiar to a typical sub-Saharan African country setting, and proceeded to validate this data with the verbatim comments from key stakeholders.

In another study conducted by Tupenaite et al. (2017), land use considerations, water efficiency considerations, energy and atmospheric considerations, materials and waste management, indoor environmental quality, and external pollution were the environmental sustainability indicators for assessing new housing development projects in the Baltic States. Though contextually, the studies reported in the literature were conducted in different settings, the environmental sustainability indicators identified in this study were almost similar to those already identified in their study. This revelation indicates that the Ghanaian construction industry can learn from other countries' environmental sustainability indicator frameworks. Notwithstanding, the utmost priority indicators must be considered to suit the local context based on the culture, legislation, policy, stakeholders, practices, and institutions as proposed by Tupenaite et al. (2017).

\subsection{Conclusion}

Environmental sustainability seeks the judicious use of natural resources and the protection of the physical environment to ensure that optimum conditions for the sustenance of various forms of life exist. Current global data points to the deteriorating state of the environment. The world is currently facing severe environmental and climate issues that require urgent attention. With the slowest global progress witnessed on SDG goals that focus on the environment (Goals $6,7,12,13,14$, and 15), there is the need to take serious steps towards implementing solutions at the project level. Given the significant toll of construction activities on the environment, the drive towards a more sustainable society cannot be possible without initiating interventions that check its negative impacts on the environment. It is well appreciated that many studies have been carried out to propose and develop various indicators for assessing the sustainability of projects. Though these developed indicators have mainly focused on all three pillars of sustainability, it is identified that the issues related to environmental sustainability are still prevalent, especially in the construction industry.

Among all the SDGs, the progress made towards achieving environment-related targets lags the other goals. There is, however, not sufficient studies, especially in a developing country setting like Ghana, that tries to examine how issues relating to environmental sustainability can be contained. There 
have been calls for researchers in typical developing country settings to contribute their quota to this issue because construction-related activities on the environment are more pronounced in developing countries than in the developed world. This current study has become necessary because the environmental evaluation systems and indicators reported in the literature are country and sector-specific in nature. This, therefore, places the onus on researchers in different countries and sectors to examine such indicator sets that best suit their countries and sectors of origin. This current study seeks to contribute to the existing state-of-the-art by examining key indicator sets for assessing the environmental sustainability of building construction projects in Ghana.

This study adopted a mixed-method approach. The design used was exploratory sequential that used qualitative data to augment the study's quantitative outcome. This design involved two stages, i.e., an initial quantitative instrument phase (where ten environmental sustainability indicator sets were identified in a critical comparative review of related literature), followed by a qualitative data collection phase. In the quantitative phase, a questionnaire was prepared and administered among certain Ghanaian construction industry stakeholders with knowledge in sustainability. Data from the quantitative phase was analysed via descriptive and inferential analysis. The data obtained from the questionnaire survey was later validated through six semi-structured interviews with respondents who are Fellows of their respective professional bodies (namely, GhIS, GIA, GhIE, CIOB), a Senior Academic (Professor in construction project delivery), and a government official. The study's findings revealed that though all the indicators were important in assessing environmental sustainability, the key and urgent indicators are the effects of the project on 'water quality, air quality, energy use and conservation, and environmental compliance management'. The interviewees further agreed to and confirmed the importance of these identified indicators for assessing the environmental sustainability of building projects in Ghana.

In comparison with existing studies, this research's fundamental novelty stems from the fact that it adopts the exploratory sequential design to identify and examine the important indicators in assessing environmental sustainability across the entire lifecycle of building projects in a typical developing country setting, i.e. Ghana. The implications of the findings are two-fold. Theoretically, this study has contributed to the current state-of-the-art by establishing key indicator sets essential for environmental sustainability of building construction projects in a typical developing country setting (in this case, Ghana), which is currently under-reported in the literature. Identifying these indicator sets advances knowledge within the subject area and provides a basis for further developing a more comprehensive index for environmental sustainability assessment in Ghana. Practically, this study's findings reveal areas of prime concern in the drive to place the local construction industry on a trajectory towards achieving environmental sustainability. All the identified indicators could help construction stakeholders effectively monitor construction activities' sustainability during projects' lifecycle. The four key indicators further identified should better position key stakeholders to put in place adequate strategies to manage building construction projects to achieve the key SDGs that focus on the environment. 
Notwithstanding the in-depth work carried out in this study, the study exhibits certain limitations. The study only sought the views of the stakeholders regarding the important environmental sustainability indicators. The researchers contend that this study's findings constitute a starting point for the eventual development of a comprehensive indicator set suitable for assessing the environmental sustainability of building projects; as such further work remains to be carried out in this direction to harness the full benefits of these findings. Although the results revealed differences in respondents' views regarding the indicators, such views were not thoroughly explored. Future studies could delve deeper into uncovering the secrets behind the differences in the respondents' opinions regarding the indicators. Furthermore, the results presented in this study only concerns one out of the three pillars of sustainability. The work can be extended by identifying and integrating social and economic indicators to constitute a holistic sustainability assessment framework. The developed indicators would serve as a pilot guideline for decision making regarding environmental sustainability of building construction projects in Ghana. Finally, though the study assumed the "universalism" stance, it did not proceed to examine the effects of respondents' background characteristics on their perception. Future study could be carried out to establish this relationship to provide a broader perspective of the issue under investigation.

\section{References}

Abramyan, S. G. (2016), "Environmental compliance during construction", Procedia Engineering, Vol. 150, pp. 2146-2149. doi: 10.1016/j.proeng.2016.07.255.

Addy, M., Adinyira, E., Danku, J. C. and Dadzoe, F. (2020), "Impediments to the development of the green building market in sub-Saharan Africa: the case of Ghana", Smart and Sustainable Built Environment, ahead-of-p(ahead-of-print). doi: 10.1108/SASBE-12-2019-0170.

Addy, M.N., Adinyira, E. and Ayarkwa, J. (2017), "Identifying and weighting indicators of building energy efficiency assessment in Ghana", Energy Procedia, Vol. 134 (2017), pp. 161-170. doi: 10.1016/j.egypro.2017.09.554.

Adinyira, E., Kwofie, T. E. and Quarcoo, F. (2018), "Stakeholder requirements for building energy efficiency in mass housing delivery: the House of Quality approach", Environment, Development and Sustainability, Vol. 20 No. 3, pp. 1115-1131. doi: 10.1007/s10668-0179930-z.

Adjarko, H., Gemadzie, J. and Agyekum, K. (2016), "Construction Related Environmental Laws and Policies in Ghana: a literature review", Asian Journal of Science and Technology, Vol. 7 No. 5, pp. 2984-2992. Available at: http://www.journalajst.com/sites/default/files/issuespdf/3027.pdf. (accessed 15 july 2020).

Afriyie, O.-W. N. Y. and Ferber, S. (2018), Access to Clean Drinking Water and Sustainable Water Management in Ghana, Accra, Ghana: 
Delegation of German Industry and Commerce in Ghana. Available at: https://www.safewaternetwork.org/file/1470/download?token=DemgAKA-. (accessed 07 April 2020).

Agyekum, K., Adinyira, E. and Oppon, A.J. (2021), "Factors limiting the adoption of hemp as an alternative sustainable building material for green building delivery in Ghana", Internationl Journal of Building Pathology and Adaptation, Vol. ahead-of-print, No. ahead-of-print, DOI: 10.1108/IJBPA-11-2020-0100.

Agyekum, K., Opoku, A., Oppon, J.A. and Opoku, D.-G.J. (2020), "Obstacles to green building project financing: an empirical study in Ghana", International Journal of Construction Management, DOI: 10.1080/15623599.2020.1832182.

Agyekum, K., Adinyira, E. and Ampratwum, G. (2020), "Factors driving the adoption of green certification of buildings in Ghana", Smart and Sustainable Built Environment, Vol. 9 No. 4, pp. 595-613.

Agyekum, K., Adinyira, E., Baiden, B., Ampratwum, G. and Duah, D. (2019), "Barriers to the adoption of green certification of buildings", Journal of Engineering, Design and Technology, Vol. 17 No. 5, pp. 1035-1055. doi: 10.1108/JEDT-01-2019-0028.

Agyekum, K., Simons, B. and Botchway, S.Y. (2018), "Factors influencing the performance of safety programmes in the Ghanaian construction industry", Acta Structilia, Vol. 25 No. 2, pp. 39-61.doi: 10.18820/24150487/as25i2.2.

Aldrich, J. O. and Cunningham, J. B. (2016), Using IBM SPSS Statistics - An Interactive Hands-On Approach. 2nd edn. California, USA: Sage Publications Inc. (ISBN: 9781483383576).

Al-Jebouri, M.F.A., Saleh, M.S., Raman, S.N., Rahmat, R.A.A.B.O.K and Shaaban, A.K. (2015), "Toward a national sustainable building assessment system in Oman: Assessment categories and their performance indicators", Sustaianble Cities and Society, Vol. 31 (2017), pp. 122-135. doi: 10.1016/j.scs.2017.02.014.

Alyami, S.H., Rezgui, Y. and Kwan, A. (2013), "Developing sustainable building assessment scheme for Saudi Arabia: Delphi consultation approach", Renewable and Sustainable Energy Reviews, Vol. 27 (2013), pp. 43-54. doi: 10.1016/j.rser.2013.06.011.

Ametepey, S. O., Aigbavboa, C. and Ansah, K. (2015), "Barriers to Successful Implementation of Sustainable Construction in the Ghanaian Construction Industry", Procedia Manufacturing, Vol. 3(Ahfe), pp. 1682-1689. doi: 10.1016/j.promfg.2015.07.988.

Ampratwum, G., Agyekum, K., Adinyira, E. and Duah, D. (2019), "A framework for the implementation of green certification of buildings in Ghana", International Journal of Construction Management, ahead-of-p(ahead-of-print). doi: 10.1080/15623599.2019.1613207.

Arora, N. K. and Mishra, I. (2019), "United Nations Sustainable Development Goals 2030 and environmental sustainability: race against time", 
Environmental Sustainability, Vol. 2 No. 4, pp. 339-342. doi: 10.1007/s42398-019-00092-y.

Ashraf, A. M., Maah, J. M. and Yusoff, I. (2014), "Soil Contamination, Risk Assessment and Remediation", in Hernandez-Soriano, M. C. (ed.) Environmental Risk Assessment of Soil Contamination. InTech, p. 55. doi: 10.5772/57287.

Asman, G.E., Kissi, E., Agyekum, K., Baiden, B.K. and Badu, E. (2019), "Critical components of environmentally sustainable buildings design practices of office buildings in Ghana", Journal of Building Engineering, Vol. 26 (2019), pp. 100925. doi: 10.1016/j.jobe.2019.100925.

Ayarkwa, J., Acheampong, A., Hackman, J.K. AND Agyekum, K. (2014), "Environmental impact of construction site activities in Ghana", Africa Develiopment and Resources Research Institute Journal, Vol. 9 No. (2), pp. 1-19.

Ballesteros, M. J., Fernández, M. D., Quintana, S., Ballesteros, J. A. and González, I. (2010), "Noise emission evolution on construction sites. Measurement for controlling and assessing its impact on the people and on the environment", Building and Environment, Vol. 45 No. 3 , pp. 711-717. doi: 10.1016/j.buildenv.2009.08.011.

Beins, B. (2009), Research methods: A tool for life (2nd ed.), Boston, MA: Pearson.

Bhosale, D. (2017),"Noise Pollution in Construction Industry and its adverse effects on construction workers", International Journal for Research in Applied Science and Engineering Technology, Vol. 5 No. 8, pp. 1423-1426. doi: 10.22214/ijraset.2017.8200.

Bossel, H. (2001), Indicators for Sustainable Development: Theory, Method, Applications. Winnipeg, Canada: International Institute for Sustainable Development. Available at: https://www.iisd.org/system/files/publications/balatonreport.pdf. (accessed 12 January 2020).

Chan, A. P. C., Darko, A., Olanipekun, A. O. and Ameyaw, E. E. (2018), "Critical barriers to green building technologies adoption in developing countries: The case of Ghana", Journal of Cleaner Production, Vol. 172, pp. 1067-1079. doi: https://doi.org/10.1016/j.jclepro.2017.10.235.

Chang, I.C. (2000), Application of factor analysis in establishing the national sustainable development evaluation indicator system for Taiwan. Ph.D Thesis, Graduate Institute of

Environmental Engineering, National Taiwan University, Taiwan.

Chen, Y.K. (2007), The establishment of assessment indicators of environmentally sustainable development and its application in Taiwan. Ph.D. Thesis, Department of Resource Engineering, National Cheng Kung University, Taiwan.

Corder, G. W. and Foreman, D. I. (2014), Nonparametric Statistics: A Step-by-Step Approach. 2nd edn. Hoboken, New Jersey: John Wiley \& Sons, Inc. (ISBN: 9781118840429). 
Dania, A. A., Kehinde, J. O. and Bala, K. (2007), "A study of construction material waste management practices by construction firms in Nigeria", Proceedings of the 3rd Scottish Conference for Postgraduate Researchers of the Built and Natural Environment. Glasgow, Scotland, pp. 121-129. Available at: https://www.irbnet.de/daten/iconda/CIB10782.pdf. (accessed 21 April 2020).

Darko, A., Chan, A. P. C. and Owusu, E. K. (2018), "What are the green technologies for sustainable housing development? An empirical study in Ghana", Business Strategy and Development, Vol. 1 No. 2, pp. 140-153. doi: 10.1002/bsd2.18.

Das, K. R. and Imon, A. H. M. R. (2016), "A Brief Review of Tests for Normality", American Journal of Theoretical and Applied Statistics, Vol. 5 No. 1, pp. 5-12. doi: 10.11648/j.ajtas.20160501.12.

Djokoto, S. D., Dadzie, J. and Ohemeng-Ababio, E. (2014), "Barriers to Sustainable Construction in the Ghanaian Construction Industry: Consultants Perspectives", Journal of Sustainable Development, Vol. 7 No. 1, pp. 134-143. doi: 10.5539/jsd.v7n1p134.

Du Plessis, C. (2002), Agenda 21 for Sustainable Construction in Developing Countries : A discussion document. Pretoria. Available at: http://hdl.handle.net/10204/3511. (accessed 30 November 2019).

Elsahragty, M. and Kim, J.-L. (2015), "Assessment and Strategies to Reduce Light Pollution Using Geographic Information Systems", Procedia Engineering, Vol. 118, pp. 479-488. doi: 10.1016/j.proeng.2015.08.458.

Enshassi, A., Kochendoerfer, B. and Al Ghoul, H. (2016), "Factors affecting sustainable performance of construction projects during project lifecycle phases". International Journal of Sustainable Construction Engineering and Technology, Vol. 7 No. 1, pp. 5068.

Fernández-Sánchez, G. and Rodríguez-López, F. (2010), "A methodology to identify sustainability indicators in construction project management - Application to infrastructure projects in Spain", Ecological Indicators, Vol. 10 No. 6, pp. 1193-1201. doi: 10.1016/j.ecolind.2010.04.009.

Field, A. (2018), Discovering Statistics Using IBM SPSS Statistics. 5th edn. London, United Kingdom: SAGE Publications Ltd. (ISBN: 9781526419521).

Fiksel, J., Eason, T. and Frederickson, H. (2012), A Framework for Sustainability Indicators at EPA, United States Environmental Protection Agency. Edited by T. Eason. Available at: https://www.epa.gov/sites/production/files/2014-10/documents/framework-for-sustainabilityindicators-at-epa.pdf. (accessed 26 November 2019). 
Green Building Council South Africa (GBCSA) (2014), Technical Manual GSSA Office V1.1. Available at: https://gbcsa.org.za/office-v1-v1-1/ (Accessed: 15 July 2020).

Geetha, M. and Ambika, D. (2015), "Study on impact of noise pollution at construction job site", International Journal of Latest Trends in Engineering and Technology, Vol. 5 No. 1, pp. 46-49. Available at: https://www.ijltet.org/journal_details.php?id=886\&j_id=2094. (accessed 11 February 2020).

George, D. and Mallery, P. (2018), IBM SPSS Statistics 25 Step by Step: A Simple Guide and Reference. 15th edn.New York, NY: Routledge. doi: $10.4324 / 9781351033909$.

Global Alliance for Buildings and Construction, International Energy Agency and United Nations Environment Programme (2019), 2019 Global Status Report for Buildings and Construction: Towards a zero-emissions, efficient and resilient buildings and construction sector (Job No: DTI/2265/PA). United Nations Environment Programme. Available at: https://www.unenvironment.org/resources/publication/2019-globalstatus-report-buildings-and-construction-sector (Accessed: 1 October 2020).

Gyamfi, S., Diawuo, F. A., Kumi, E. N., Sika, F. and Modjinou, M. (2018), "The energy efficiency situation in Ghana', Renewable and Sustainable Energy Reviews, Vol. 82 No. 1, pp. 1415-1423. doi: 10.1016/j.rser.2017.05.007.

Hammer, C.S. (2011), "The importance of participants demographics", American Journal of Speech-Language Pathology, Editorial. DOI: 10.1044/1058-0360(2011/ed-04).

Hassan, O. A. B. (2016), "An integrated approach to assessing the sustainability of buildings", Journal of Engineering, Design and Technology, Vol. 14 No. 4, pp. 835-850. doi: 10.1108/JEDT-12-2014-0077.

Hill, R.C. and Bowen, P. (1997), “Sustainable construction: Principles and a framework for attainment". Construction Management and Economics, Vol. 15 (1997), pp. 223-239.

Houser, D. L. and Pruess, H. (2009), "The effects of construction on water quality: a case study of the culverting of Abram Creek", Environmental Monitoring and Assessment, Vol. 155 No. 1-4, pp. 431-442. doi: 10.1007/s10661-008-0445-9.

Hozatli, B. and Gunerhan, H. (2015), "with reinforced concrete and wood material in terms of Mugla province. Engineer and Machine, Vol. 56 (660), pp. 52-60.

Hu, M. (2017), "Balance between energy conservation and environmental impact: Life-cycle energy analysis and life-cycle environmental impact analysis". Energy and Buildings, Vol. 140 (2017), pp. 131-139. 
International Energy Agency (2018), The Future of Cooling. Opportunities for energyefficient air conditioning, available at: http://www.oecd.org/about/publishing/TheFutureofCooling2018Corrigendumpa..., accessed 13 March 2021.

International Resource Panel (IRP) (2017), Assessing global resource use: a Systems approach to resource efficiency and pollution reduction. Nairobi, Kenya.: United Nations Environment Programme. Available at: https://www.resourcepanel.org/reports/assessing-global-resourceuse. (accessed 12 July 2020).

Ioana-Alina, C. and Nicoleta, N. (2017), "Measuring Air Quality in a Construction Site Biotope Using the AQM-65 Analyser", IOP Conference Series: Materials Science and Engineering, 245, p. 052019. doi: 10.1088/1757-899X/245/5/052019.

Kaatz, E., Root, B. and Bowen, P. (2005), "Broadening project participation through a modified building sustainability assessment". Journal of Civil Engineering and Management, Vol. 33 No. 5, pp. 441-454.

Kamali, M. and Hewage, K.N. (2015), "Performance indicators for sustainability assessment of buildings", Procs. $5^{\text {th }}$ International/11 th Construction Specialty Conference, 8-10 June 2015, Vancouver, British Columbia, pp. 1-11.

Kibert, C. J. (2013), Sustainable construction: Green building design and delivery. 3rd edn. Hoboken, New Jersey: John Wiley \& Sons, Inc. (ISBN: 0470904453)

Kivilä, J., Martinsuo, M. and Vuorinen, L. (2017), "Sustainable project management through project control in infrastructure projects", International Journal of Project Management, Vol. 35 No. 6, pp. 1167-1183. doi: 10.1016/j.ijproman.2017.02.009.

Labuschagne, C. and Brent, A.C. (2005), "Sustainable project lifecycle management: The need to integrate lifecycles in the manufacturing sector". International Journal of Project Management, Vol. 23 (2005), pp. 159-168.

Labuschagne, C. and Brent, A.C. (2004), Sustainable project lifecycle management: Aligning project management methodologies with the principles of sustainable development", In Procs. 2004 PMSA International Conference, Johannesburg, South Africa, 10-12 May 2004, pp. 104-115. 
Lin, H.T. (2016), "GHG emission reduction performance of state-of-the-art green buildings: Review of two case studies". Renewable Sustainable and Energy Review, Vol. 56 (2016), pp. 484-493.

Majdalani, Z., Ajam, M. and Mezher, T. (2006), "Sustainability in the construction industry: a Lebanese case study". Construction Innovation: Information, Process, Management, Vol. 6 No. 1, pp. 33-46.

Marcelino-Sádaba, S., González-Jaen, L.F. and Pérez-Ezcurdia, A. (2015), "Using project management as a way to sustainability: From a comprehensive review to framework definition". Journal of Cleaner Production, Vol. 99 (2015), pp. 1-16.

Markiv, T., Sobol, K., Franus, M. and Franus, W. (2016), "Mechanical and durability properties of concretes incorporating zeolite". Architecture, Civil and Mechanical Engineering, Vol. 16 (2016), pp. 554-562.

Mason, J. (2002), Qualitative Researching, $2^{\text {nd }}$ ed., SAGE Publications, London

Masters-Williams, H., Heap, A., Kitts, H., Greenshaw, L., Davis, S., Fisher, Pe., Hendrie, M. and Owens, D. (2001), Control of water pollution from construction sites: Guidance for consultants and contractors (C532). London, United Kingdom. Construction Industry Research and Information Association (CIRIA). (ISBN: 9780860175322).

Murnane, E., Heap, A. and Swain, A. (2006), Control of water pollution from linear construction sites: Technical guidance (C648). London, United Kingdom: Construction Industry Research and Information Association (CIRIA). (ISBN: 9780860176480).

Ofori-Kuragu, J. K., Baiden, B. K. and Badu, E. (2017), Transforming Construction in Ghana. An action agenda for enabling world-class construction and infrastructure development for accelerated industrialisation. 1st edn. Accra, Ghana: Project Excellence. (ISBN: 9789988265717).

Opoku, A. (2016), "SDG2030: A Sustainable Built Environment's Role in Achieving the Post-2015 United Nations Sustainable Development Goals", Proceedings of the 32nd Annual ARCOM Conference. Manchester, United Kingdom: Association of Researchers in Construction Management, pp. 1101-1110. Available at: https://www.arcom.ac.uk/-docs/archive/2016-ARCOM-Full-Proceedings-Vol-2.pdf. (accessed 27 May 2020)

Opoku, A. (2019), "Biodiversity and the built environment: Implications for the Sustainable Development Goals (SDGs)", Resources, 
Conservation and Recycling, Vol. 141(September), pp. 1-7. doi: 10.1016/j.resconrec.2018.10.011.

Opoku, A. and Fortune, C. (2013), "Implementation of Sustainable Practices in UK Construction Organizations: Drivers and Challenges", The International Journal of Sustainability Policy and Practice, Vol. 8 No. 1, pp. 121-132. doi: 10.18848/2325-1166/CGP/v08i01/55360.

Opoku, D.-G. J., Ayarkwa, J. and Agyekum, K. (2019), "Barriers to environmental sustainability of construction projects", Smart and Sustainable Built Environment, Vol. 8 No. 4, pp. 292-306. doi: 10.1108/SASBE-08-2018-0040.

Opoku, D.-G., Agyekum, K. and Ayarkwa, J. (2019), "Drivers of environmental sustainability of construction projects: a thematic analysis of verbatim comments from built environment consultants", International Journal of Construction Management, ahead-of-print. doi: $10.1080 / 15623599.2019 .1678865$.

Osei, V. (2013), "The Construction Industry and its Linkages to the Ghanaian Economy - Policies to Improve the Sector's Performance", International Journal of Development and Economic Sustainability, Vol. 1 No. 1, pp. 56-72. Available at: https://www.eajournals.org/journals/international-journal-of-development-and-economic-sustainability-ijdes/vol-1-issue-1-march-

2013/the-construction-industry-and-its-linkages-to-the-ghanaian-economy-polices-to-improve-the-sectors-performance/. (accessed 18 June 2020)

Owusu, P. A. and Asumadu-Sarkodie, S. (2016), "A review of renewable energy sources, sustainability issues and climate change mitigation", Cogent Engineering, Vol. 3 No. 1, pp. 1-14. doi: 10.1080/23311916.2016.1167990.

Pakzad, P., Osmond, P. and Corkery, L. (2017), "Developing Key Sustainability Indicators for Assessing Green Infrastructure Performance", Procedia Engineering, Vol. 180, pp. 146-156. doi: 10.1016/j.proeng.2017.04.174.

Pallant, J. (2016), SPSS Survival Manual: A step by step guide to data analysis using IBM SPSS. 6th edn. Milton Keynes, United Kingdom: Open University Press. (ISBN: 9780335261543).

Parse, RR (1990), "Parse's research methodology with an illustration of the lived experience of hope", Nursing Science Quarterly, Vol. 3 No. 1, pp. 9-17

Patil, N. A., Tharun, D. and Laishram, B. (2016), "Infrastructure development through PPPs in India: criteria for sustainability assessment", Journal of Environmental Planning and Management, Vol. 59 No. 4, pp. 708-729. doi: 10.1080/09640568.2015.1038337.

Pitt, M., Tucker, M., Riley, M. and Longden, J. (2009), "Towards sustainable construction: promotion and best practices", Construction Innovation, Vol. 9 No. 2, pp. 201-224. doi: 10.1108/14714170910950830. 
Polit, F.P. and Beck, C.T. (2017). Nursing Research: generating and Assessing Evidence for Nursing Practice, 10th ed., Wolters Kluwer, Philadelphia, New York, NY.

Rahimian, F.P., Goulding, J., Akintoye, A. and Kolo, S. (2017), "Review of motivations, success factors, and barriers to the adoption of offsite manufacturing in Nigeria", Procedia Engineering, Vol. 196 (2017), pp. 512-519.

Reddy, M. (2016), "Evaluation of Sustainability Assessment Indicators for an Infrastructure Project", International Journal of Engineering Science and Computing, Vol. 6 No. 5, pp. 5673-5677. doi: 10.4010/2016.1383.

Rodriguez-Trejo, S., Ahmad, A.M., Hafeez, M.A., Dawood, H., Vukovic, V., Kassem, M., Naji, K.K. and Dawood, N. (2017), "Hierarchy based information requirements for sustainable operations of buildings in Quatar", Sustainable Cities and Society, Vol. 32 (2017), pp. 435-448.

Roe, D., Seddon, N. and Elliott, J. (2019), Biodiversity loss is a development issue: a rapid review of evidence, IIED Issue Paper. London. Available at: https://pubs.iied.org/pdfs/17636IIED.pdf. (accessed 09 January 2020).

Sachs, J. D., Schmidt-Traub, G., Kroll, C., Lafortune, G. and Fuller, G. (2019), Sustainable Development Report 2019: Transformations to achieve the Sustainable development Goals. New York, USA: Bertelsmann Stiftung and Sustainable Development Solutions Network (SDSN. Available at: https://www.sdgindex.org/reports/sustainable-development-report-2019/ (Accessed: 20 September 2020).

Sadler, L. (2005), Construction and its impact on Air Quality Exceedances. Available at: http://www.airqualitypolicy.co.uk/sadler_files/pdf/Construction report for PRECIS.pdf. (accessed 06 February 2020)

Safety and Health (2015), Silicosis: what it is and how to avoid it, available at: https://www.safetyandhealthmagazine.com/articles/12507-silicosis-what-it-is-and-how-to-avoid-it, accessed 13 March 2021.

Sfakianaki, E. (2015), "Resource-efficient construction: rethinking construction towards sustainability", World Journal of Science, Technology and Sustainable Development, 12(3), pp. 233-242. doi: 10.1108/WJSTSD-03-2015-0016.

Shen, L.-Y., Hao, J. L., Tam, V. W.-Y. and Yao, H. (2007), "A checklist for assessing sustainability performance of construction projects", Journal of Civil Engineering and Management, Vol. 13 No. 4, pp. 273-281. doi: 10.3846/13923730.2007.9636447.

Shen, L., Wu, Y. and Zhang, X. (2011), "Key Assessment Indicators for the Sustainability of Infrastructure Projects", Journal of construction engineering and management, Vol. 137 No. 6, pp. 1125-1130. doi: 10.1061/(ASCE)CO.1943-7862 .0000315.

Siew, R. Y. J., Balatbat, M. C. A. and Carmichael, D. G. (2016), "A proposed framework for assessing the sustainability of infrastructure", International Journal of Construction Management, Vol. 16 No. 4, pp. 281-298. doi: 10.1080/15623599.2016.1146115.

Talukhaba, A. A., Phungula, B. and Manchidi, M. B. (2013), "Managing the Efficient Use of Energy on Construction Sites and Cost Reduction", 
Proceedings SB13 Southern Africa Conference. Cape Town, South Africa: Department of Built Environment, Central University of Technology, Free State, pp. 252-260. Available at: http://www.irbnet.de/daten/iconda/CIB_DC26255.pdf. (accessed 30 November 2019).

Tong, R., Cheng, M., Zhang, L., Liu, M., Yang, X., Li, X. and Yin, W. (2018), "The construction dust-induced occupational health risk using Monte-Carlo simulation", Journal of Cleaner Production, Vol. 184, pp. 598-608. doi: 10.1016/j.jclepro.2018.02.286.

Tupenaite, L., Lill, I., Geipele, I. and Naimaviciene, J. (2017), "Ranking of Sustainability Indicators for Assessment of the New Housing Development Projects: Case of the Baltic States", Resources, Vol. 6 No. 4, pp. 1-21. doi: 10.3390/resources6040055.

Ugwu, O. O., Kumaraswamy, M. M., Wong, A. and Ng, S. T. (2006), "Sustainability appraisal in infrastructure projects (SUSAIP): Part 2: A case study in bridge design", Automation in Construction, Vol. 15 No. 2, pp. 229-238. doi: 10.1016/j.autcon.2005.05.005.

Ugwu, O. O. and Haupt, T. C. (2007), "Key performance indicators and assessment methods for infrastructure sustainability-a South African construction industry perspective", Building and Environment, Vol. 42 No. 2, pp. 665-680. doi: 10.1016/j.buildenv.2005.10.018.

United Nations Environment Programme (UNEP) (2013), Embedding the Environment in Sustainable Development Goals: UNEP Post-2015 Discussion Paper 1, Version 2. Nairobi, Kenya.: United Nations Environment Programme. Available at: http://www.unep.org/pdf/embedding-environments-in-SDGs-v2.pdf. (accessed 27 May 2020).

United States Green Building Council, USGBC, (2018), LEED v4 neighbourhood development guide, 2018. Available at: https://www.usgbc. org/guide/nd, accessed 14 March 2020.

Vallero, D. J. and Vallero, D. A. (2019), 'Land Pollution', in Letcher, T. M. and Vallero, D. A. (eds) Waste: A Handbook for Management. 2nd edn. London, United Kingdom: Elsevier Inc., pp. 631-648. doi: 10.1016/B978-0-12-815060-3.00032-3.

Vanderley, J. M. (2011), "Sustainable Construction, Innovation and Durability: Trends and Research Needs", Proceedings of 12th International Conference on Durability of Building Materials and Components. Porto, Portugal: International Council for Research and Innovation in Building and Construction (CIB), p. 7. Available at: https://www.irbnet.de/daten/iconda/CIB22296.pdf. (accessed 30 November 2019).

Vatalis, K. I., Manoliadis, O., Charalampides, G., Platias, S. and Savvidis, S. (2013), "Sustainability Components Affecting Decisions for Green Building Projects", Procedia Economics and Finance, Vol. 5 (2013), pp. 747-756. doi: 10.1016/S2212-5671(13)00087-7.

Waidyasekara, K. G. A. S., De Silva, L. and Rameezdeen, R. (2016), "Water use efficiency and conservation during construction: drivers, barriers and practices", Built Environment Project and Asset Management, Vol. 6 No. 5, pp. 553-566. doi: 10.1108/BEPAM-09-20150052 . 
Waidyasekara, K. G. A. S., De Silva, M. L. and Rameezdeen, R. (2012), "Value of Sustainable Use of Water in Construction Industry", Proceedings of 2nd International Conference on Sustainable Built Environment (ICSBE). Yogyakarta, Indonesia: Faculty of Civil Engineering and Planning, Universitas Islam Indonesia. Available at: http://dl.lib.mrt.ac.lk/handle/123/9032. (accessed 30 October 2019).

Wang, N. (2014), "The role of the construction industry in China's sustainable urban development", Habitat International, 44, pp. 442-450. doi: 10.1016/j.habitatint.2014.09.008.

Waylen, C., Thornback, J. and Garrett, J. (2011), Water: An Action plan on reducing water usage on construction sites. London, United Kingdom: Construction Products Association. Available at: http://www.constructionproducts.org.uk/. (accessed 13 November 2019).

Wieser, A. A., Scherz, M., Maier, S., Passer, A. and Kreiner, H. (2019), "Implementation of Sustainable Development Goals in construction industry - a systemic consideration of synergies and trade-offs", IOP Conference Series: Earth and Environmental Science, 323, p. 012177. doi: 10.1088/1755-1315/323/1/012177.

Wisdom, J. and Creswell, J.W. (2013), "Integrating quantitative and qualitative data collection and analysis while studying patient-centred medical home models", Rockville, MD: Agency for Healthcare Research and Quality. AHRQ Publication No. 13-0028-EF.

World Green Building Council (2021), Air quality in the built environment, available at: https://worldgbc.org/clean-air-buildings/impacts, accessed 13 March 2021.

World Health Organisation (2018), Ambient (outdoor) air quality and health, available at: https://www.who.int/news-room/fact-sheets/detail/ambient-(outdoor)-air-quality-and-health, accessed 13 March 2021

Wu, J., Guo, Y. and Zhou, J. (2020), "Nexus between ecological conservation and soci-economic development and its dynamics: Insights from a case in China". Water, Vol. 12 (2020), pp. 1-19.

Yalley, P. P.-K., Opintan-Baah, E. and Darko, J. O. (2013), "Evaluating the Performance of Environmental Protection Agency (EPA) in the Ghanaian building constructional industries (a case study area Kumasi and Sekondi Takoradi Metropolises)", International Refereed Journal of Engineering and Science, Vol. 2 No. 1, pp. 1-8. Available at: http://www.irjes.com/Papers/vol2-issue1/A210108.pdf. (accessed 30 April 2020).

Yan, H., Ding, G., Li, H., Wang, Y., Zhang, L., Shen, Q. and Feng, K. (2019), "Field Evaluation of the Dust Impacts from Construction Sites on Surrounding Areas: A City Case Study in China", Sustainability, Vol. 11 No. 7, pp. 1-19. doi: 10.3390/su11071906.

Yao, H. (2007), "Assessing the Sustainability Performance of Infrastructure Projects", Proceedings of the International Conference on Sustainable Building Asia (SBO7 Seoul). Seoul, Korea: International Council for Research and Innovation in Building and Construction (CIB), pp. 393-402. Available at: https://bit.ly/35NUJV7. (accessed 30 September 2019). 
Yao, H., Shen, L., Tan, Y. and Hao, J. (2011), "Simulating the impacts of policy scenarios on the sustainability performance of infrastructure projects", Automation in Construction, Vol. 20 No. 8, pp. 1060-1069. doi: 10.1016/j.autcon.2011.04.007.

Yeleliere, E., Cobbina, S. J. and Duwiejuah, A. B. (2018), "Review of Ghana's water resources: the quality and management with particular focus on freshwater resources", Applied Water Science, Vol. 8 No. 3, pp. 1-12. doi: 10.1007/s13201-018-0736-4.

Yin, R.K. (2014), Case Study Research: Design and Methods, $5^{\text {th }}$ ed.,Sage,Thousand Oaks,CA.

Younan, A. (2011), Developing a green building rating system for Egypt. A Ph.D Thesis submitted to the Department of Construction and Architectural Engineering, American University in Cairo, available at: http://dar.aucegypt.edu/handle/10526/2286, accessed 14 March 2021.

Yu, W.-d., Cheng, S.-t., Ho, W.-c. and Chang, Y.-H. (2018), "Measuring the sustainability of construction projects throughout their lifecycle: A Taiwan lesson", Sustainability, Vol. 10, pp. 1-16.

Yu, W.-d., Cheng, S.T., Miao, C.M. and Perng, G.y. (2017), “Green innovation of green roof technology- A case study”. Materials Science and Engineering Technology, Vol. 48 (2017), pp. 420-429.

Yüksek, I. and Karadayi, T.T. (2017), "Energy-efficient building design in the context of building life-cylce". IntechOpen, available at: https://www.intechopen.com/books/energy-efficient-buildings/energy-efficient-building-design-in-the-context-of-building-life-cycle, accessed 13 March 2021.

Zhou, L., Keivani, R. and Kurul, E. (2013), "Sustainability performance measurement framework for PFI projects in the UK", Journal of Financial Management of Property and Construction, Vol. 18 No. 3, pp. 232-250. doi: 10.1108/JFMPC-08-2012-0032.

Zielińska-Dabkowska, K. M., Xavia, K. and Bobkowska, K. (2020), "Assessment of citizens' actions against light pollution with guidelines for future initiatives", Sustainability, Vol. 12 No. 1), p. 4997. doi: 10.3390/su12124997.

Table I Environmental indicators and references 
ENV01 = Environmental Compliance and Management; ENV02 = Impact on soil/land resources; ENV03 = Effect on air quality; ENV04 = Noise pollution; ENV05 = Light pollution; ENV06 = Effect on water quality; ENV07 = Water use and conservation; ENV08 = Impact on

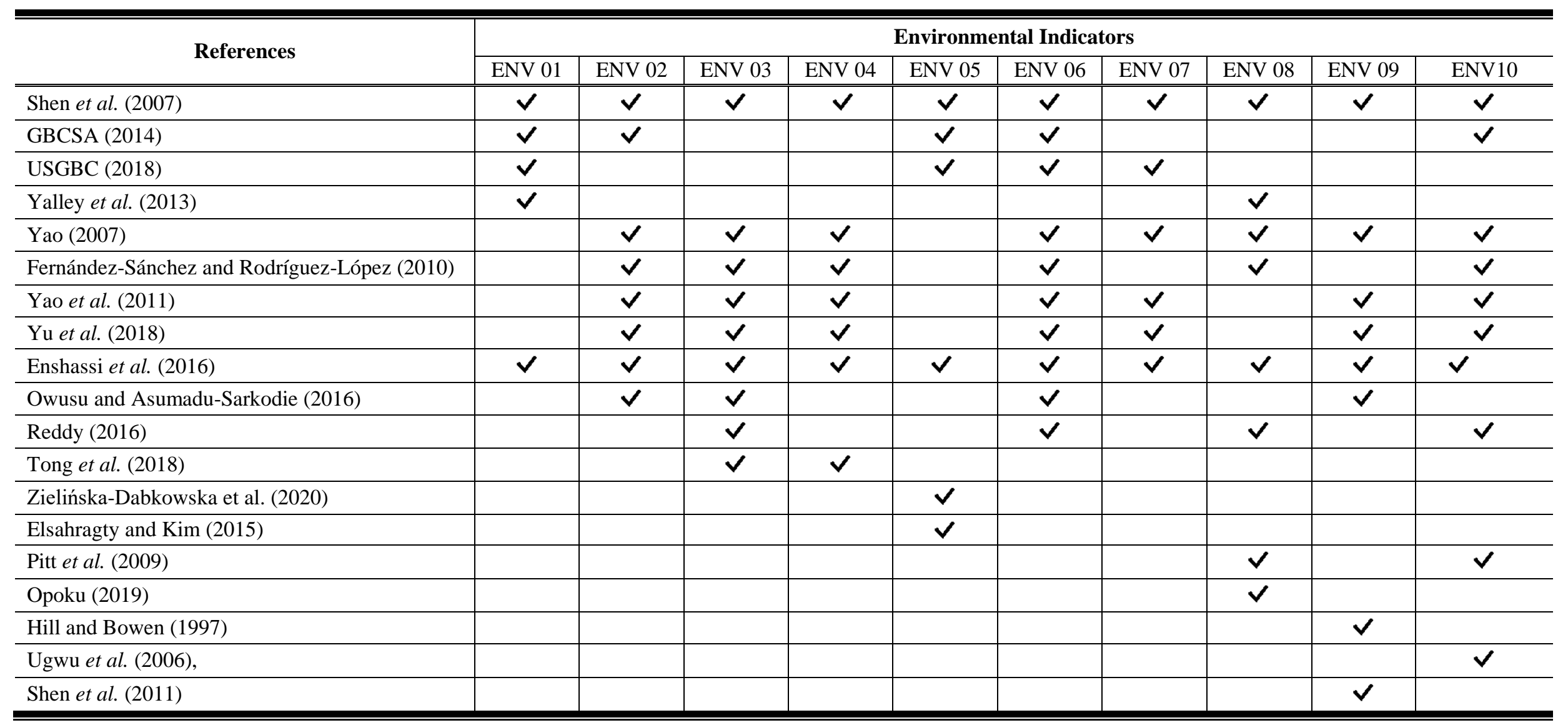

ecology and biodiversity; ENV09 = Energy use and conservation; ENV10 = Construction and demolition waste management. 
Table II Stakeholder Perception of Significance of Environmental Sustainability Indicators

\begin{tabular}{|c|c|c|c|c|c|c|c|c|c|c|c|c|c|c|c|c|c|c|}
\hline \multirow[t]{2}{*}{ Code } & \multicolumn{3}{|c|}{ Client } & \multicolumn{3}{|c|}{ Contractor } & \multicolumn{3}{|c|}{ Consultant } & \multicolumn{3}{|c|}{ Government } & \multicolumn{3}{|c|}{ Academics } & \multicolumn{3}{|c|}{ Overall } \\
\hline & Mean & SD & Rank & Mean & SD & Rank & Mean & SD & Rank & Mean & SD & Rank & Mean & SD & Rank & Mean & SD & Rank \\
\hline ENV06 & 4.49 & 0.651 & 1 & 4.44 & 0.847 & 4 & 4.61 & 0.545 & 1 & 3.63 & 0.916 & 1 & 4.57 & 0.507 & 2 & 4.50 & 0.667 & 1 \\
\hline ENV03 & 4.32 & 0.475 & 2 & 4.33 & 1.000 & 8 & 4.56 & 0.603 & 2 & 3.00 & 1.309 & 6 & 4.57 & 0.517 & 3 & 4.40 & 0.760 & 2 \\
\hline ENV09 & 4.08 & 0.795 & 7 & 4.48 & 0.975 & 3 & 4.39 & 0.640 & 8 & 3.50 & 0.756 & 2 & 4.83 & 0.388 & 1 & 4.35 & 0.769 & 3 \\
\hline ENV01 & 4.30 & 0.661 & 3 & 4.44 & 0.892 & 6 & 4.46 & 0.627 & 3 & 3.25 & 0.886 & 5 & 4.30 & 0.470 & 5 & 4.34 & 0.718 & 4 \\
\hline ENV07 & 4.27 & 0.652 & 4 & 4.44 & 0.880 & 5 & 4.43 & 0.668 & 6 & 2.88 & 1.356 & 10 & 4.43 & 0.507 & 4 & 4.32 & 0.794 & 5 \\
\hline ENV02 & 4.22 & 0.479 & 5 & 4.37 & 0.742 & 7 & 4.44 & 0.554 & 4 & 3.38 & 0.744 & 4 & 4.13 & 0.244 & 7 & 4.29 & 0.602 & 6 \\
\hline ENV08 & 4.22 & 0.750 & 6 & 4.48 & 0.893 & 2 & 4.42 & 0.645 & 7 & 2.88 & 1.126 & 8 & 4.26 & 0.449 & 6 & 4.29 & 0.785 & 7 \\
\hline ENV10 & 4.03 & 0.687 & 9 & 4.48 & 0.700 & 1 & 4.33 & 0.671 & 9 & 3.50 & 0.765 & 3 & 4.13 & 0.344 & 8 & 4.22 & 0.680 & 8 \\
\hline ENV04 & 4.05 & 0.575 & 8 & 4.22 & 0.847 & 9 & 4.43 & 0.526 & 5 & 2.88 & 1.136 & 9 & 4.13 & 0.364 & 9 & 4.20 & 0.696 & 9 \\
\hline ENV05 & 3.49 & 0.870 & 10 & 4.00 & 0.832 & 10 & 3.61 & 0.815 & 10 & 3.00 & 1.195 & 7 & 4.00 & 1.044 & 10 & 3.67 & 0.908 & 10 \\
\hline
\end{tabular}

Table III Reliability Analysis, Normality Analysis, and Kruskal-Wallis Test Results

\begin{tabular}{|c|c|c|c|c|c|c|c|c|c|}
\hline \multirow[t]{3}{*}{ Code } & \multirow{3}{*}{$\begin{array}{c}\text { Reliability } \\
\text { Analysis }\end{array}$} & \multicolumn{6}{|c|}{ Normality Testing } & \multirow{2}{*}{\multicolumn{2}{|c|}{$\begin{array}{c}\text { KW Test Statistics } \\
(\text { Degrees of freedom }=4)\end{array}$}} \\
\hline & & \multicolumn{2}{|c|}{ Skewness $($ Standard Error $=\mathbf{0 . 1 8 8})$} & \multicolumn{2}{|c|}{ Kurtosis $($ Standard Error $=0.374)$} & \multicolumn{2}{|c|}{ Shapiro-Wilk } & & \\
\hline & & Statistic & Z-scores & Statistic & Z-scores & Statistic & Significance & $\begin{array}{c}\text { Chi- } \\
\text { Square }\end{array}$ & $\begin{array}{l}\text { Asymptotic } \\
\text { Significance }\end{array}$ \\
\hline ENV01 & 0.661 & -0.910 & -4.840 & 0.575 & 1.537 & 0.768 & 0.000 & 16.567 & 0.002 \\
\hline ENV02 & 0.811 & -0.387 & -2.059 & 0.315 & 0.842 & 0.748 & 0.000 & 22.924 & 0.000 \\
\hline ENV03 & 0.742 & -1.555 & -8.271 & 3.252 & 8.695 & 0.715 & 0.000 & 16.126 & 0.003 \\
\hline ENV04 & 0.824 & -1.156 & -6.149 & 3.282 & 8.775 & 0.737 & 0.000 & 25.717 & 0.000 \\
\hline ENV05 & 0.522 & -0.568 & -3.021 & -0.226 & -0.604 & 0.850 & 0.000 & 13.764 & 0.008 \\
\hline ENV06 & 0.675 & -1.246 & -6.628 & 1.349 & 3.607 & 0.705 & 0.000 & 10.344 & 0.035 \\
\hline ENV07 & 0.803 & -1.453 & -7.729 & 2.687 & 7.184 & 0.732 & 0.000 & 12.734 & 0.013 \\
\hline ENV08 & 0.771 & -1.162 & -6.181 & 1.329 & 3.553 & 0.755 & 0.000 & 19.077 & 0.001 \\
\hline ENV09 & 0.744 & -1.266 & -6.734 & 2.024 & 5.412 & 0.753 & 0.000 & 27.959 & 0.000 \\
\hline ENV10 & 0.730 & -0.540 & -2.872 & 0.174 & 0.465 & 0.790 & 0.000 & 19.403 & 0.001 \\
\hline
\end{tabular}


Table IV Pairwise Comparisons of Stakeholders' Perception of Significance of ENSIs

\begin{tabular}{|c|c|c|c|c|c|c|c|c|c|}
\hline Code & $\begin{array}{c}\text { Stakeholder - Stakeholder } \\
\text { Comparison }\end{array}$ & $\begin{array}{c}\text { Test } \\
\text { Statistic }\end{array}$ & Significance & $\begin{array}{c}\text { Adjusted } \\
\text { Significance }\end{array}$ & Code & $\begin{array}{c}\text { Stakeholder - Stakeholder } \\
\text { Comparison }\end{array}$ & $\begin{array}{c}\text { Test } \\
\text { Statistic }\end{array}$ & Significance & $\begin{array}{c}\text { Adjusted } \\
\text { Significance }\end{array}$ \\
\hline \multirow{10}{*}{ ENV01 } & Government-Academics & -46.736 & 0.009 & 0.093 & \multirow{10}{*}{ ENV06 } & Government-Clients & 42.387 & 0.010 & 0.098 \\
\hline & Government-Clients* & 49.617 & 0.004 & $0.037 *$ & & Government-Contractors & 45.174 & 0.008 & 0.077 \\
\hline & Government-Consultants* & 60.396 & 0.000 & $0.002 *$ & & Government-Academics & -45.367 & 0.009 & 0.087 \\
\hline & Government-Contractors* & 65.525 & 0.000 & $0.002 *$ & & Government-Consultants* & 50.146 & 0.001 & $0.014 *$ \\
\hline & Academics-Clients & 2.880 & 0.804 & 1.000 & & Clients-Contractors & -2.787 & 0.794 & 1.000 \\
\hline & Academics-Consultants & 13.659 & 0.193 & 1.000 & & Clients-Academics & -2.980 & 0.790 & 1.000 \\
\hline & Academics-Contractors & 18.789 & 0.131 & 1.000 & & Clients-Consultants & -7.759 & 0.362 & 1.000 \\
\hline & Clients-Consultants & -10.779 & 0.224 & 1.000 & & Contractors-Academics & -0.193 & 0.987 & 1.000 \\
\hline & Clients-Contractors & -15.909 & 0.151 & 1.000 & & Contractors-Consultants & -4.972 & 0.601 & 1.000 \\
\hline & Consultants-Contractors & 5.130 & 0.604 & 1.000 & & Academics-Consultants & 4.779 & 0.636 & 1.000 \\
\hline \multirow[t]{10}{*}{ ENV02 } & Government-Academics & -40.174 & 0.021 & 0.205 & \multirow[t]{10}{*}{ ENV07 } & Government-Clients & 40.074 & 0.018 & 0.183 \\
\hline & Government-Clients* & 47.541 & 0.004 & $0.039 *$ & & Government-Academics & -48.793 & 0.006 & 0.063 \\
\hline & Government-Contractors* & 63.426 & 0.000 & $0.002 *$ & & Government-Consultants* & 51.896 & 0.001 & $0.014 *$ \\
\hline & Government-Consultants* & 65.361 & 0.000 & $0.000 *$ & & Government-Contractors* & 57.380 & 0.001 & $0.011 *$ \\
\hline & Academics-Clients & 7.367 & 0.511 & 1.000 & & Clients-Academics & -8.719 & 0.451 & 1.000 \\
\hline & Academics-Contractors & 23.252 & 0.052 & 0.524 & & Clients-Consultants & -11.822 & 0.180 & 1.000 \\
\hline & Academics-Consultants & 25.187 & 0.013 & 0.128 & & Clients-Contractors & -17.305 & 0.116 & 1.000 \\
\hline & Clients-Contractors & -15.885 & 0.137 & 1.000 & & Academics-Consultants & 3.102 & 0.766 & 1.000 \\
\hline & Clients-Consultants & -17.821 & 0.037 & 0.370 & & Academics-Contractors & 8.586 & 0.487 & 1.000 \\
\hline & Contractors-Consultants & -1.935 & 0.839 & 1.000 & & Consultants-Contractors & 5.484 & 0.577 & 1.000 \\
\hline \multirow[t]{10}{*}{$\overline{\text { ENV03 }}$} & Government-Clients & 36.848 & 0.028 & 0.285 & \multirow[t]{10}{*}{ ENV08 } & Government-Academics & -46.497 & 0.010 & 0.098 \\
\hline & Government-Contractors* & 49.931 & 0.004 & $0.040 *$ & & Government-Clients* & 49.306 & 0.004 & $0.039^{*}$ \\
\hline & Government-Academics* & -55.397 & 0.002 & $0.018^{*}$ & & Government-Consultants* & 60.771 & 0.000 & $0.002 *$ \\
\hline & Government-Consultants* & 56.847 & 0.000 & $0.004 *$ & & Government-Contractors* & 71.340 & 0.000 & $0.001 *$ \\
\hline & Clients-Contractors & -13.083 & 0.231 & 1.000 & & Academics-Clients & 2.808 & 0.809 & 1.000 \\
\hline & Clients-Academics & -18.549 & 0.105 & 1.000 & & Academics-Consultants & 14.274 & 0.174 & 1.000 \\
\hline & Clients-Consultants & -19.999 & 0.022 & 0.219 & & Academics-Contractors & 24.843 & 0.046 & 0.458 \\
\hline & Contractors-Academics & -5.466 & 0.655 & 1.000 & & Clients-Consultants & -11.465 & 0.196 & 1.000 \\
\hline & Contractors-Consultants & -6.917 & 0.477 & 1.000 & & Clients-Contractors & -22.035 & 0.047 & 0.471 \\
\hline & Academics-Consultants & 1.450 & 0.888 & 1.000 & & Consultants-Contractors & 10.569 & 0.285 & 1.000 \\
\hline \multirow[t]{10}{*}{$\overline{\text { ENV04 }}$} & Government-Clients & 41.671 & 0.011 & 0.109 & \multirow[t]{10}{*}{ ENV09 } & Government-Clients & 30.777 & 0.071 & 0.710 \\
\hline & Government-Academics & -44.541 & 0.010 & 0.097 & & Government-Consultants* & 47.361 & 0.004 & $0.037 *$ \\
\hline & Government-Contractors* & 58.525 & 0.001 & $0.005^{*}$ & & Government-Contractors* & 61.380 & 0.000 & $0.005^{*}$ \\
\hline & Government-Consultants* & 67.806 & 0.000 & $0.000 *$ & & Government-Academics* & -76.880 & 0.000 & $0.000 *$ \\
\hline & Clients-Academics & -2.870 & 0.797 & 1.000 & & Clients-Consultants & -16.584 & 0.061 & 0.608 \\
\hline & Clients-Contractors & -16.855 & 0.113 & 1.000 & & Clients-Contractors & -30.603 & 0.006 & 0.057 \\
\hline & Clients-Consultants* & -26.135 & 0.002 & $0.021 *$ & & Clients-Academics* & -46.103 & 0.000 & $0.001 *$ \\
\hline & Academics-Contractors & 13.985 & 0.240 & 1.000 & & Consultants-Contractors & 14.019 & 0.155 & 1.000 \\
\hline & Academics-Consultants & 23.265 & 0.021 & 0.206 & & Consultants-Academics* & -29.519 & 0.005 & $0.048 *$ \\
\hline & Contractors-Consultants & -9.280 & 0.327 & 1.000 & & Contractors-Academics & -15.501 & 0.211 & 1.000 \\
\hline \multirow[t]{10}{*}{ ENV05 } & Government-Clients & 18.311 & 0.292 & 1.000 & \multirow{10}{*}{ ENV10 } & Government-Clients & 30.965 & 0.068 & 0.677 \\
\hline & Government-Consultants & 24.528 & 0.140 & 1.000 & & Government-Academics & -33.524 & 0.060 & 0.603 \\
\hline & Government-Contractors & 46.074 & 0.010 & 0.102 & & Government-Consultants* & 50.715 & 0.002 & $0.017 *$ \\
\hline & Government-Academics & -46.609 & 0.011 & 0.109 & & Government-Contractors* & 62.438 & 0.000 & $0.004 *$ \\
\hline & Clients-Consultants & -6.217 & 0.491 & 1.000 & & Clients-Academics & -2.560 & 0.824 & 1.000 \\
\hline & Clients-Contractors & -27.763 & 0.014 & 0.139 & & Clients-Consultants & -19.751 & 0.025 & 0.247 \\
\hline & Clients-Academics & -28.298 & 0.017 & 0.168 & & Clients-Contractors* & -31.473 & 0.004 & $0.042 *$ \\
\hline & Consultants-Contractors & 21.546 & 0.032 & 0.322 & & Academics-Consultants & 17.191 & 0.099 & 0.987 \\
\hline & Consultants-Academics & -22.081 & 0.039 & 0.387 & & Academics-Contractors & 28.913 & 0.019 & 0.191 \\
\hline & Contractors-Academics & -0.535 & 0.966 & 1.000 & & Consultants-Contractors & 11.722 & 0.232 & 1.000 \\
\hline
\end{tabular}

\footnotetext{
* significant differences in the perceived significance of ENSIs
} 


\section{APPENDIX \\ QUESTIONNAIRE \\ ENVIRONMENTAL PERFORMANCE INDICATORS FOR ASSESSING SUSTAINABILITY AT THE CONSTRUCTION PHASE OF BUILDING PROJECTS}

Please provide the correct information by ticking $[\checkmark]$ the appropriate box and fill in the blank spaces where necessary.

\section{Section A - Respondent Profile}

1. Indicate your highest-level academic qualification

[ ] Diploma/HND/Professional certificate

[ ] Bachelor's degree

[ ] Postgraduate diploma/certificate

[ ] Master's degree

[ ] Doctorate degree

2. Within which of the construction stakeholder organisations below do you primarily operate?

[ ] Client organisation

[ ] Contractor organisation

[ ] Consultancy firm

[ ] Government agency

[ ] Academic/Research institution

[ ] Other. Please specify

\section{Section B - Environmental Sustainability Indicators}

The following indicators have been identified to be useful in the assessment of the environmental sustainability of infrastructure projects. Indicate on a scale of $1-5$, the significance of these indicators for assessing the sustainability performance of building projects during their construction phase.

\begin{tabular}{|c|c|c|c|c|}
\hline $\mathbf{1}$ & $\mathbf{2}$ & $\mathbf{3}$ & $\mathbf{4}$ & $\mathbf{5}$ \\
\hline Not significant & Fairly significant & Significant & Very Significant & Extremely significant \\
\hline
\end{tabular}

\begin{tabular}{|c|c|c|c|c|c|c|c|}
\hline CODE & ENVIRONMENTAL SUSTAIANABILITY INDICATORS & 1 & 2 & 3 & 4 & & 5 \\
\hline ENV01 & Environmental Compliance and Management & & & & & & \\
\hline ENV02 & Impact on soil/land resources & & & & & & \\
\hline ENV03 & Effect on air quality & & & & & & \\
\hline ENV04 & Noise pollution & & & & & & \\
\hline ENV05 & Light pollution & & & & & & \\
\hline ENV06 & Effect on water quality & & & & & & \\
\hline ENV07 & Water use and conservation & & & & & & \\
\hline
\end{tabular}




\begin{tabular}{|l|l|l|l|l|l|l|}
\hline ENV08 & Impact on ecology and biodiversity & & & & \\
\hline ENV09 & Energy use and conservation & & & & & \\
\hline ENV10 & Construction waste management & & & & & \\
\hline
\end{tabular}

QUALITATIVE DATA COLLECTION INSTRUMENT

Following the quantitative data collection and analysis, four environmental sustainability indicators were identified as key in all phases of building construction projects. We would be grateful if you could briefly explain how you think these indicators contribute to environmental sustainability across the various lifecycles of building projects.

1. The project's effect on water quality

2. The project's effect on air quality

3. The project's effect on energy use and conservation

4. The project's effect on environmental compliance and management 